\title{
Penetrative DNA intercalation and G-base selectivity of an organometallic tetrahydroanthracene $\mathrm{Ru}^{\mathrm{II}}$ anticancer complex $\dagger$
}

\author{
Hong-Ke Liu, ${ }^{* a}$ John A. Parkinson, ${ }^{c}$ Juraj Bella, $^{e}$ Fuyi Wang $^{d}$ and Peter J. Sadler ${ }^{* b}$
}

Received 20th February 2010, Accepted 6th May 2010

DOI: 10.1039/c0sc00175a

The organometallic $\mathrm{Ru}^{\mathrm{II}}$ arene complex $\left[\left(\eta^{6}-\text { tha }\right) \mathrm{Ru}(\mathrm{en}) \mathrm{Cl}\right]^{+}(\mathbf{1})$, where tha $=$ tetrahydroanthracene and en = ethylenediamine, is potently cytotoxic towards cancer cells. We have used a combination of HPLC, ESI-MS, 1D- and 2D-NMR, including $\left[{ }^{1} \mathrm{H},{ }^{1} \mathrm{H}\right]$ ROESY, NOESY, $\left[{ }^{1} \mathrm{H},{ }^{15} \mathrm{~N}\right] \mathrm{HSQC}$ (using $\left.{ }^{15} \mathrm{~N}-\mathbf{1}\right)$, and $\left[{ }^{1} \mathrm{H},{ }^{31} \mathrm{P}\right]$ experiments to elucidate the role of the non-aromatic, bulky rings of tha in adducts with the DNA hexamer d(CGGCCG), since DNA is a potential target for this drug. Reactions of 1 with single-stranded $\mathrm{d}(\mathrm{CGGCCG})$ gave rise to ruthenation at each of the three $\mathrm{G}$ bases, whereas reactions of the duplex $d(C G G C C G)_{2}$ with 1 mol equiv. 1 led to exclusive ruthenation of $G^{3}$ and $G^{6}$ (and $G^{9}, G^{12}$ ) and not $G^{2}$ (or $G^{8}$ ). Addition of a second mol equiv. of 1 gave di-ruthenated adducts (major sites $G^{3} / G^{6}$, $\left.G^{6} / G^{9}, G^{2} / G^{6}\right)$, and on reaction with a third mol equiv. tri-ruthenation $\left(G^{2}, G^{3} / G^{6} / G^{12}\right)$. The NMR data are indicative of the coordinative binding of Ru-tha specifically to $\mathrm{G}^{3}$ and $\mathrm{G}^{6}$, together with penetrative intercalation of the bulky non-coordinated tha rings $\mathrm{B}$ and $\mathrm{C}$ of $\mathbf{1}^{\prime}$, selectively between two base pairs $\mathrm{G}^{3} / \mathrm{C}^{10}: \mathrm{C}^{4} / \mathrm{G}^{9}$ and $\mathrm{G}^{6} / \mathrm{C}^{7}: \mathrm{C}^{5} / \mathrm{G}^{8}$. Intercalation at $\mathrm{GpC}$ base steps by tha has a lower energy penalty compared to intercalation at $\mathrm{GpG}$ base steps, thereby allowing accommodation of tha. Monointercalation of tha reduced the strength of H-bonding between en-NH and GO6. These differences in structural distortions compared to cisplatin induced by the coordinative binding of Ru-tha to GN7 may contribute to the differences in mechanism of action, including protein recognition of the metallated lesions, and lack of cross resistance.

\section{Introduction}

There is currently much interest in the design and mechanism of action of ruthenium anticancer complexes. ${ }^{1-7}$ Structural distortions of DNA are thought to play a major role in the anticancer activity of many ruthenium and other transition metal complexes. ${ }^{1,8-23}$ It is apparent that distortions induced in DNA by $\left[\left(\eta^{6} \text {-arene }\right) \mathrm{Ru}(\mathrm{en}) \mathrm{Cl}\right]^{+}$organometallic ruthenium(II) arene anticancer complexes ${ }^{1,21,24-28}$ (en $=$ ethylenediamine) differ significantly from those induced by cisplatin. ${ }^{9,10}$ In particular the arene appears to play a significant role in DNA interactions and the cytotoxicity of complexes shows a strong dependence on the arene. ${ }^{19,22,23,29,31}$ The cytotoxic activity of these ruthenium arene complexes appears to increase with the size of the coordinated arene: ${ }^{1,24,25} p$-cymene $(\mathrm{Ru}$-cym) < biphenyl (Ru-bip) < dihydroanthracene $(\mathrm{Ru}-\mathrm{dha})<$ tetrahydroanthracene (Ru-tha, $\mathbf{1}$,

${ }^{a}$ Jiangsu Key Laboratory of Biofunctional Materials, School of Chemistry, Nanjing Normal University, Nanjing, China.E-mail: liuhongke@njnu.edu. cn; Tel: +86-2585891651

${ }^{b}$ Department of Chemistry, University of Warwick, Gibbet Hill Road, Coventry, UK CV4 7AL. E-mail: P.J.Sadler@warwick.ac.uk; Fax: +442476523819; Tel: +44-2476523818

${ }^{c}$ WestCHEM Department of Pure and Applied Chemistry, University of Strathclyde, 295 Cathedral Street, Glasgow, UK G1 1 XL

${ }^{d B}$ Beijing National Laboratory for Molecular Sciences, Institute of Chemistry, Chinese Academy of Sciences, Beijing, 100190, China

${ }^{e}$ School of Chemistry, University of Edinburgh, King's Buildings, West Mains Road, Edinburgh, UK EH9 $3 J J$

$\dagger$ Electronic supplementary information (ESI) available: Reactions of II with ${ }^{15} \mathrm{~N}-1$. HPLC, HPLC-ESI-MS, NMR and $\mathrm{pH}$ measurements, Tables S1-S7 and Figs. S1-S7. See DOI: 10.1039/c0sc00175a
Fig. 1), the latter complex being as cytotoxic as the clinical platinum drug cisplatin. If the arene is extended, the possibility arises of intercalation between DNA base-pairs. Studies of the interactions of ruthenium complexes Ru-cym and Ru-bip with the 6-mer duplex d(CGGCCG $)_{2}$ revealed that the binding of $\mathrm{Ru}$ to GN7 is accompanied by strong H-bonding between GO6 and en-NH, and that the arene ligand distorts the duplex either via steric interactions (Ru-cym) or via intercalation ${ }^{19,22,23,32,38}$ (Ru-bip), which may explain why the $\mathrm{IC}_{50}$ values of complexes Ru-cym and Ru-bip are similar. ${ }^{1,24,25}$ Further work $^{23}$ revealed

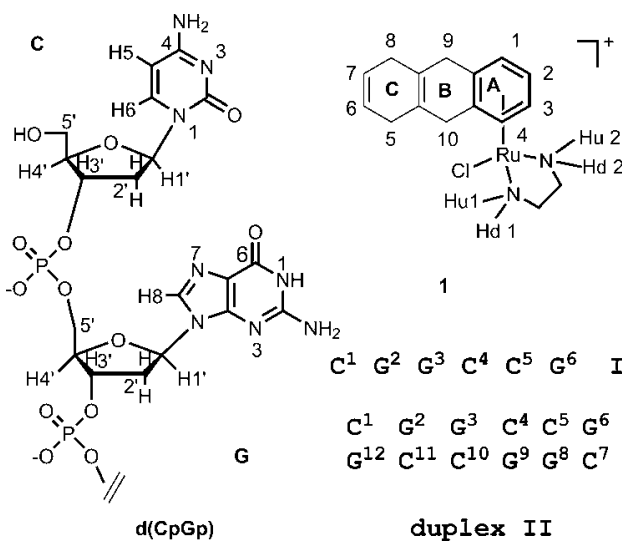

Fig. 1 Structures and NMR numbering schemes for $\left[\left(\eta^{6}-\text { tha }\right) \mathrm{Ru}(\mathrm{en}) \mathrm{Cl}\right]^{+}$ (1) and for the $5^{\prime}-\mathrm{d}(\mathrm{CpGp})$ fragment of the hexamer d(CGGCCG); single-strand (ss) I and duplex II. 
a unique mode of binding of Ru-bip to a 14-mer DNA duplex: the monofunctional fragment $\left\{\left(\eta^{6} \text {-biphenyl }\right) \mathrm{Ru}(\mathrm{en})\right\}^{2+}$ is highly specific for GN7, although mobile at elevated temperature (migrating to other $\mathrm{G}$ residues). The uncoordinated phenyl ring of bip can be involved in $\pi-\pi$ stacking with DNA bases either via classical intercalation ${ }^{19,35-38}$ between the bases, or with a partially extruded T base. . $3,39,40^{2}$

Arene-base stacking may play a role in determining the rates of reactions of $\mathrm{Ru}^{\mathrm{II}}$ arene complexes with DNA, as appears to be the case for mononucleotides. We have shown previously that the tha and bip arenes can exert slightly different effects on the chemical reactivity of these $\mathrm{Ru}^{\mathrm{II}}$ complexes and on distortions induced in DNA. ${ }^{26,29,30}$ For example the rate of reaction of $\mathrm{Ru}$ bip with cGMP is $c a .2 \times$ slower than that of $1,{ }^{27}$ but Ru-bip induces similar unwinding of DNA as complex $1\left(14^{\circ}\right) .{ }^{26}$ Both of these complexes can potentially intercalate into DNA, leading to "downstream" effects on DNA processing and repair mechanisms. Ru-bip is an aromatic intercalator, ${ }^{22,23,41}$ in which all the protons of the extended ring are within the aromatic plane, and can form $\pi-\pi$ interactions with bases; however, the extended rings $\mathrm{B}$ and $\mathrm{C}$ of tha in $\mathbf{1}$ are bulky non-aromatic groups; the three rings $\mathrm{A}, \mathrm{B}$ and $\mathrm{C}$ are not in the same plane and the $\mathrm{H} 5,8$ and $\mathrm{H} 9,10$ protons are located above or below the arene ring plane by nearly $0.9 \AA$. The extended rings $\mathrm{B}$ and $\mathrm{C}$ cannot form $\pi-\pi$ interactions with bases in the same way that aromatic intercalators do and so Ru-tha is more sterically demanding than Rubip. It is reasonable to predict that the intercalative interactions between duplex DNA and Ru-tha or Ru-bip should be quite different. The Ru-tha complex $\mathbf{1}$ is 10 times more toxic to cancer cells than Ru-bip. ${ }^{24,25}$

Bulky substituents at the sites of DNA lesions may activate nucleotide-excision repair, ${ }^{42,43}$ however, reports of intercalation by bulky molecules are rare. Gomez-Pinto et al. ${ }^{44}$ have shown that intercalation of a modified nucleotide containing a cholesterol derivative into a DNA decamer induces DNA distortions which are different from those induced by aromatic intercalators. ${ }^{45,46}$

Threading intercalation has attracted recent attention because the intercalator occupies and interacts strongly with both the minor and major grooves of DNA simultaneously. This has been observed for polyaromatic intercalators, ${ }^{47-49}$ dinuclear metallointercalators, ${ }^{50-53}$ and platinum complexes with aromatic side-arms, such as acridine-9-ylthiourea. ${ }^{54-56}$ As a result, threading intercalative interactions promise high DNA binding affinity and specificity, a slow rate of dissociation, and an enhanced ability to block DNA-protein interactions. ${ }^{50,57}$

It is important to understand the mode of interaction between $\left[\left(\eta^{6} \text {-tha }\right) \mathrm{Ru}(\mathrm{en}) \mathrm{Cl}\right]^{+}$(1) and DNA since a major contributor to its high potency appears to be the lack of repair of the lesions formed on DNA by this complex, ${ }^{29}$ i.e. lack of recognition by repair enzymes. In the present work we have investigated the role of the extended non-aromatic bulky tha in interactions of $\left[\left(\eta^{6} \text {-tha) } \mathrm{Ru}(\mathrm{en}) \mathrm{Cl}\right]^{+}\right.$(1) with the single-stranded hexamer d(CGGCCG) and double-stranded duplex $\mathrm{d}(\mathrm{CGGCCG})_{2}$ using a wide variety of experimental techniques including HPLC, ESI-MS and 1D ${ }^{1} \mathrm{H}$ and $2 \mathrm{D}\left[{ }^{1} \mathrm{H},{ }^{1} \mathrm{H}\right] \mathrm{ROESY}$, NOESY, $\left[{ }^{1} \mathrm{H},{ }^{15} \mathrm{~N}\right]$ HSQC (using ${ }^{15} \mathrm{~N}-1$ ), and $\left[{ }^{1} \mathrm{H},{ }^{31} \mathrm{P}\right] \mathrm{NMR}$ spectroscopy.

\section{Results}

Scheme 1 indicates the reaction pathways that were followed during the course of this study. HPLC enabled separation of single DNA strands even for reactions of the duplex. The $1: 1$, $2: 1$ and $3: 1$ 1/I mixtures, $1.1: 1$ and $2: 1$ 1/II mixtures were studied by HPLC and ESI-MS, and $1.1: 1,2: 1$ and $3: 1 \mathbf{1 / I I}$ mixtures were studied by $1 \mathrm{D}{ }^{1} \mathrm{H}$ and $2 \mathrm{D}\left[{ }^{1} \mathrm{H},{ }^{1} \mathrm{H}\right]$ TOCSY NMR experiments. The $1.1: 1 \mathbf{1} / \mathrm{II}$ mixture was studied by $1 \mathrm{D}{ }^{1} \mathrm{H}, 2 \mathrm{D}$ ${ }^{15} \mathrm{~N}$-decoupled $\left[{ }^{1} \mathrm{H},{ }^{1} \mathrm{H}\right]$ ROESY, NOESY, ${ }^{15} \mathrm{~N}$-edited $\left[{ }^{1} \mathrm{H},{ }^{1} \mathrm{H}\right]$ TOCSY and NOESY, 2D ${ }^{15} \mathrm{~N}$-decoupled $\left[{ }^{1} \mathrm{H},{ }^{15} \mathrm{~N}\right]$ and $\left[{ }^{1} \mathrm{H},{ }^{31} \mathrm{P}\right]$ HSQC NMR experiments using ${ }^{15} \mathrm{~N}$-en labelled 1. A nearcomplete NMR spectral assignment of the NOESY NMR spectrum of the $1.1: 1 \mathbf{1} /$ II mixture was achieved, although its complexity precluded full structure determination. Assignments were made possible by the known selectivity of $\mathbf{1}$ for guanines, and the localization of structural perturbations to residues close to the ruthenated $\mathrm{G}$ residue. Thus, sequential assignments along each strand always led to cross-peaks largely identical to those of the non-ruthenated duplex. Despite extensive overlap of NOE cross-peaks, little ambiguity in the assignments of individual resonances was found, with cross-validation of signal assignments from related connectivities being possible, with the help of $\left[{ }^{1} \mathrm{H},{ }^{31} \mathrm{P}\right] \mathrm{HSQC},\left[{ }^{1} \mathrm{H},{ }^{15} \mathrm{~N}\right] \mathrm{HSQC}$ and ${ }^{15} \mathrm{~N}$-edited $\left[{ }^{1} \mathrm{H},{ }^{1} \mathrm{H}\right] \mathrm{NOESY}$

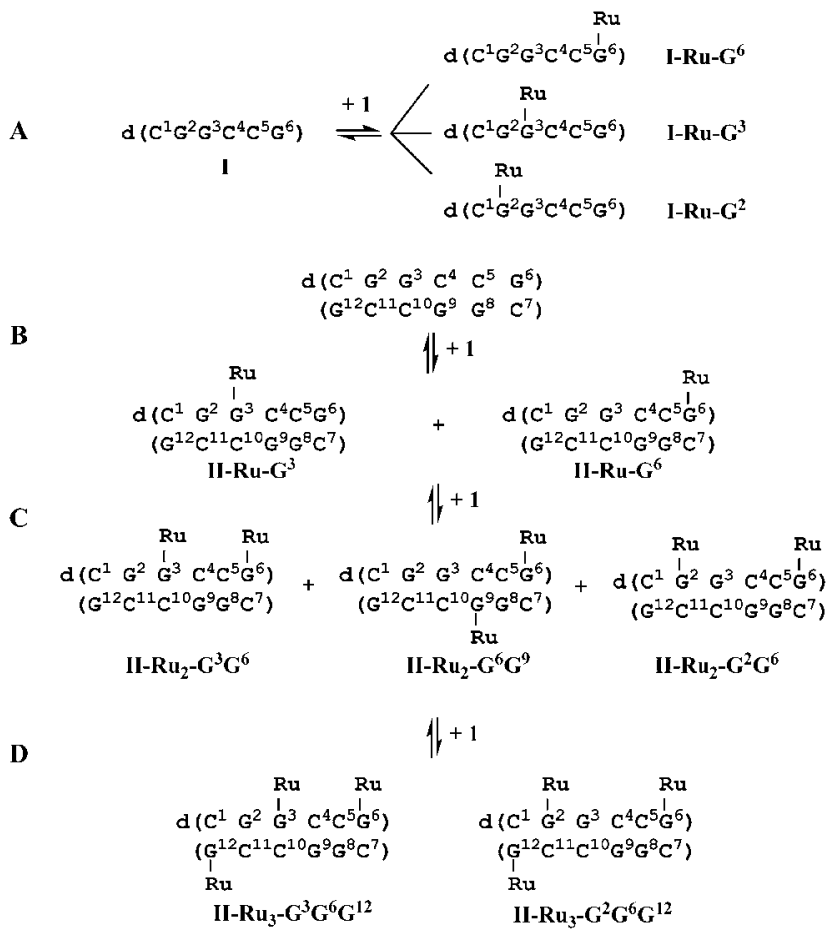

Scheme 1 (A) Reaction of single-stranded (ss) hexamer I ( $0.1 \mathrm{mM})$ with $1 \mathrm{~mol}$ equiv. of $\mathbf{1}$ in $\mathrm{H}_{2} \mathrm{O}, 310 \mathrm{~K}$ for $48 \mathrm{~h}$, gives three mono-ruthenated $\mathbf{I}$ (I-Ru-G ${ }^{2}$, I-Ru-G ${ }^{3}, \mathbf{I}-\mathrm{Ru}-\mathrm{G}^{6}$ ). (B) Reaction of double-stranded (ds) hexamer II $\left(0.3 \mathrm{mM}, 0.1 \mathrm{M} \mathrm{NaClO}_{4}\right)$ with $1.1 \mathrm{~mol}$ equiv. of $\mathbf{1}$ in $90 \% \mathrm{H}_{2} \mathrm{O} /$ $10 \% \mathrm{D}_{2} \mathrm{O}$ gives rise to two mono-ruthenated duplexes II-Ru-G $\mathrm{G}^{3}$ and II-Ru- $\mathrm{G}^{6}$ as products. Addition of a second mol equiv. of $\mathbf{1}$ results in diruthenated duplexes, including $\mathbf{I I}-\mathrm{Ru}_{2}-\mathrm{G}^{3} \mathrm{G}^{6}, \mathbf{I I}-\mathrm{Ru}_{2}-\mathrm{G}^{6} \mathrm{G}^{9}$ and $\mathbf{I I}-\mathrm{Ru}_{2}-$ $\mathrm{G}^{2} \mathrm{G}^{6}$ as main products. Addition of a third mol equiv. of 1 results in two tri-ruthenated duplexes II-R $u_{3}-G^{3} G^{6} G^{12}$ and II- $R u_{3}-G^{2} G^{6} G^{12}$ as main products. $\mathrm{Ru}=\left\{\left(\eta^{6} \text {-tha }\right) \mathrm{Ru}(\mathrm{en})\right\}^{2+}, \mathbf{1}^{\prime}$. For structure of $\mathbf{1}$, see Fig. 1. 
experiments and HPLC-MS data. 2D ${ }^{15} \mathrm{~N}$-decoupled $\left[{ }^{1} \mathrm{H},{ }^{1} \mathrm{H}\right]$ ROESY and NOESY and ${ }^{15} \mathrm{~N}$-decoupled $\left[{ }^{1} \mathrm{H},{ }^{15} \mathrm{~N}\right]$ HSQC NMR data were also acquired for $2: 1$ and $3: 1$ 1/II mixtures, but the spectra were too complex for interpretation.

\section{HPLC and ESI-MS characterization of products from ss-DNA I +1}

A $100 \mu \mathrm{M}$ aqueous solution of $\mathbf{1}$ was incubated with $\mathbf{I}$ at $310 \mathrm{~K}$ at $\mathrm{Ru}$ : I molar ratios of $1: 1,2: 1$ and $3: 1$ for $48 \mathrm{~h}$ in the dark, and these were then analyzed by HPLC. The low ionic strength $\left(5.1 \times 10^{-4} \mathrm{M}\right)$ ensures that this self-complementary oligonucleotide remains largely single-stranded (calculated melting temperature $264 \mathrm{~K}$ ) under these conditions. ${ }^{58} \mathrm{New}$ peaks were observed for each reaction (Fig. 2 and Table S1 $\dagger$ ), and the adducts associated with them were identified subsequently by ESI-MS. The peaks for the observed negative ions are listed in Table $\mathrm{S} 1 . \dagger$ Reaction at a $\mathrm{Ru}: \mathbf{I}$ molar ratio of $1: 1$ resulted in three mono-ruthenated products together with three di-ruthenated products. Reaction at a $\mathrm{Ru}: \mathbf{I}$ molar ratio of $2: 1$ resulted in three di-ruthenated products together with a tri-ruthenated

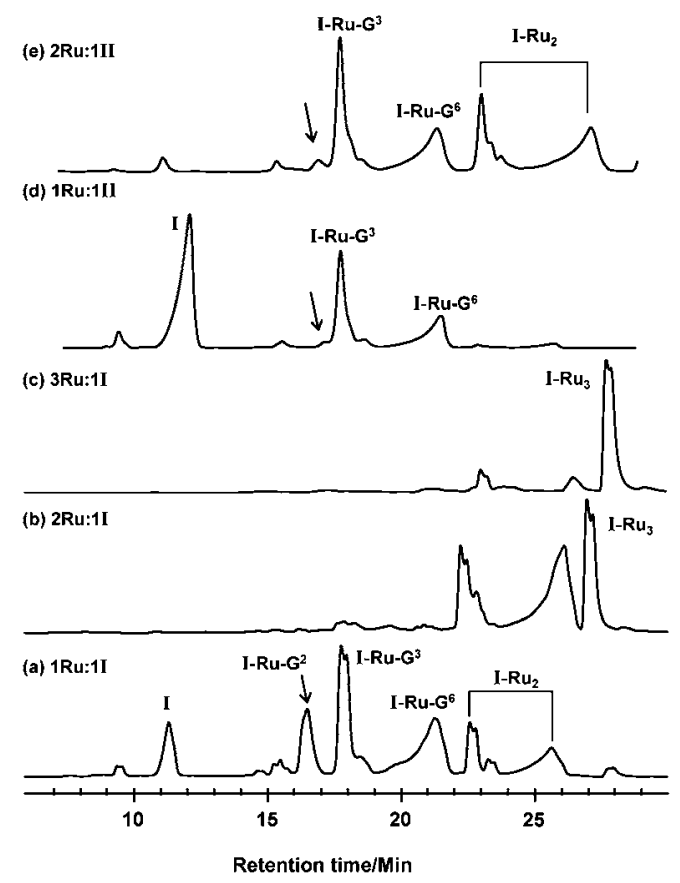

Fig. 2 HPLC chromatograms for reaction of $\left[\left(\eta^{6}-\text { tha }\right) \mathrm{Ru}(\mathrm{en}) \mathrm{Cl}\right]^{+}(\mathbf{1})$ with single-stranded (ss) d(CGGCCG) (I) $\left(0.1 \mathrm{mM}\right.$ in $\left.\mathrm{H}_{2} \mathrm{O}\right)$ at $\mathrm{Ru}:$ I mol ratios of (a) $1: 1$, (b) $2: 1$, and (c) $3: 1$, and for reaction of 1 with duplex $\mathrm{d}(\mathrm{CGGCCG})_{2}$ (II) $\left(0.34 \mathrm{mM}, 0.1 \mathrm{M} \mathrm{NaClO}_{4}, 90 \% \mathrm{H}_{2} \mathrm{O} / 10 \% \mathrm{D}_{2} \mathrm{O}\right)$ at a Ru : II mol ratio of (d) $1.1: 1$ and (e) $2: 1$. The mono-ruthenated duplex II-R $\mathrm{u}_{1}$ elutes as mono-ruthenated ss-DNA I (I-Ru-G ${ }^{3}$ and I-Ru$\mathrm{G}^{6}$; species I-Ru-G $\mathrm{G}^{3}$ and $\mathbf{I}-\mathrm{Ru}-\mathrm{G}^{9}$ are identical, as are $\mathbf{I}-\mathrm{Ru}-\mathrm{G}^{6}$ and $\mathbf{I}-\mathrm{Ru}-$ $\mathrm{G}^{12}$ ); di-ruthenated duplex II-R $\mathrm{u}_{2}$ elutes as mono-ruthenated ss-DNA I (I-Ru-G $\mathrm{G}^{3}$ and $\mathbf{I}-\mathrm{Ru}-\mathrm{G}^{6}$, see (d)), and di-ruthenated ss-DNA I $\left(\mathbf{I}-\mathrm{Ru}_{2}\right.$, see (e)). It is notable that $\mathrm{G}^{2}$ is readily ruthenated for single strand $\mathbf{I}$ (see $\mathbf{I}$ Ru- $\mathrm{G}^{2}$ in (a)) but not for duplex II in (d). Little ruthenation on $\mathrm{G}^{8}$ was observed when 1 mol equiv. of $\mathbf{1}$ was added to mono-ruthenated duplexes II-Ru-G $\mathrm{G}^{3}$ and II-Ru-G $(\mathrm{e}) . \mathrm{Ru}=\left\{\left(\eta^{6} \text {-tha }\right) \mathrm{Ru}(\mathrm{en})\right\}^{2+}\left(\mathbf{1}^{\prime}\right)$, and is bound to $\mathrm{G}^{3} \mathrm{~N} 7$ or $\mathrm{G}^{6} \mathrm{~N} 7$; for DNA sequence, see Fig. 1 and Scheme 1 . product. Reaction at a $\mathrm{Ru}:$ I molar ratio of $3: 1$, gave only one main HPLC peak corresponding to a tri-ruthenated product.

\section{HPLC and ESI-MS characterization of products from reaction of duplex II + 1}

An aqueous solution of $\mathbf{1}$ was incubated with duplex II in $0.1 \mathrm{M}$ $\mathrm{NaClO}_{4}$ at ambient temperature for $24 \mathrm{~h}$ at a $\mathrm{Ru}$ : II molar ratio of $1.1: 1$ in an NMR tube in the dark. This gave rise to HPLC peaks which were identified by ESI-MS as ss-DNA I and two mono-ruthenated single-stranded products (see Fig. 2(d), Table $\mathrm{S} 1 \dagger$ ), with relative peak area ratios of $2: 1$. Another equimolar amount of $\mathbf{1}$ was then added to give a $\mathrm{Ru}$ : II molar ratio of $2: 1$, and was kept at ambient temperature in the dark for $48 \mathrm{~h}$. This gave HPLC peaks which were identified by ESIMS as two mono-ruthenated and two di-ruthenated singlestranded products (see Fig. 2(e) and Table S1†).

\section{NMR characterization of products}

Assignments of the ${ }^{1} \mathrm{H}$ NMR peaks for the ruthenated DNA duplexes were made on the basis of established methods developed for studying right-handed B-DNA duplexes by NMR spectroscopy. ${ }^{59}$ The assignments of the ${ }^{1} \mathrm{H}$ NMR resonances of free DNA duplex II have been reported by Lam and Au-Yeung ${ }^{60}$ and the ${ }^{1} \mathrm{H}$ and ${ }^{31} \mathrm{P}$ chemical shifts are listed in Table $\mathrm{S} 2 . \dagger$ Terminal $\left(3^{\prime}\right)$ base resonance assignments were identified from NOESY NMR data sets and were based on ordering of the $\mathrm{H}^{\prime}$ and $\mathrm{H} 2^{\prime \prime}$ proton chemical shifts $\left(\mathrm{H} 2^{\prime}>\mathrm{H} 2^{\prime \prime}\right)$ compared with the other nucleotide units $\left(\mathrm{H} 2^{\prime}<\mathrm{H} 2^{\prime \prime}\right)$. The resonance assignments of backbone ${ }^{31} \mathrm{P}$ and sugar ring ${ }^{1} \mathrm{H}\left(\mathrm{H}^{\prime}\right.$ and $\left.\mathrm{H}^{\prime}\right)$ resonances for free and mono-ruthenated DNA duplexes were achieved by $\left[{ }^{1} \mathrm{H}\right.$, ${ }^{31} \mathrm{P}$ ] HSQC NMR experiments ${ }^{61}$ and the $\mathrm{H} 4{ }_{\mathrm{n}}^{\prime}$ and $\mathrm{H} 3{ }_{\mathrm{n}-1}^{\prime}$ protons were assigned by correlation to their respective ${ }^{31} \mathrm{P}_{\mathrm{n}}$ resonances. The assignments of ruthenated $\mathrm{G}^{*} \mathrm{H} 8$ and $\mathbf{1}^{\prime}$-en- $\mathrm{NH}_{2}{ }^{1} \mathrm{H}(\mathrm{NHu}$ and NHd, see Fig. 1 for labelling) resonances of mono-ruthenated DNA duplexes were achieved by reference to $2 \mathrm{D}\left[{ }^{1} \mathrm{H},{ }^{15} \mathrm{~N}\right]$ HSQC and ${ }^{15} \mathrm{~N}$-edited $\left[{ }^{1} \mathrm{H},{ }^{1} \mathrm{H}\right]$ NOESY NMR data. The NMR chemical shifts of the ${ }^{1} \mathrm{H}$ and ${ }^{31} \mathrm{P}$ resonances associated with these two mono-ruthenated duplex adducts are listed in Table S3 (II$\mathrm{Ru}-\mathrm{G}^{3}$ ), Table S4 (II-Ru-G6) and Table S2 (free II). $\dagger$ The assignments of $\mathrm{H} 1,4, \mathrm{H} 2,3, \mathrm{H} 9,10, \mathrm{H} 5,8, \mathrm{H} 6,7$ and $\mathbf{1}^{\prime}$-en- $\mathrm{NH}_{2}$ (NHu and NHd, see Fig. 1 for labelling) ${ }^{1} \mathrm{H}$ NMR resonances of $\left\{\left(\eta^{6} \text {-tha }\right) \mathrm{Ru}(\mathrm{en})\right\}^{2+}\left(\mathbf{1}^{\prime}\right)$ were achieved by $2 \mathrm{D}\left[{ }^{1} \mathrm{H},{ }^{15} \mathrm{~N}\right] \mathrm{HSQC}$, ${ }^{15} \mathrm{~N}$-edited $\left[{ }^{1} \mathrm{H},{ }^{1} \mathrm{H}\right]$ NOESY and $\left[{ }^{1} \mathrm{H},{ }^{1} \mathrm{H}\right]$ NOESY experiments $^{27,28}$ and are listed in Table 1 and Fig. 5. The assignments of $\mathrm{H} 2,3$ and H1,4 NMR resonances of $\mathbf{1}^{\prime}$ were achieved by correlations to the $\mathbf{1}^{\prime}$-en-NHu resonances in $\left[{ }^{1} \mathrm{H},{ }^{1} \mathrm{H}\right]$ NOESY NMR data, where the $\mathrm{H} 9,10$ protons were assigned by correlation to the $\mathrm{H} 1,4$ resonances, and $\mathrm{H} 5,8$ protons by correlation to the $\mathrm{H} 9,10$ and $\mathrm{H} 6,7$ resonances. ${ }^{27,28}$

\section{NMR of $1.1: 1,2: 1$ and $3: 1$ 1/II reactions}

Fig. S1 shows the imino and aromatic region of the $800 \mathrm{MHz} 1 \mathrm{D}$ ${ }^{1} \mathrm{H}$ NMR spectrum of DNA duplex II in the absence (Fig. S1A $\dagger$ ) and presence of $1 \mathrm{~mol}$ (Fig. $\mathrm{S} 1 \mathrm{~B} \dagger$ ), $2 \mathrm{~mol}$ (Fig. $\mathrm{S} 1 \mathrm{C} \dagger$ ) and $3 \mathrm{~mol}$ (Fig. S1D $\dagger$ ) equiv. of $\mathbf{1}$. Reaction with $1.1 \mathrm{~mol}$ equiv. of $\mathbf{1}$ resulted in the formation of a number of new peaks for II (especially near $8.5 \mathrm{ppm}\left(\mathrm{G}^{*} \mathrm{H} 8\right), 13.0-13.6 \mathrm{ppm}$ (imino) and 
Table $1{ }^{1} \mathrm{H}$ NMR chemical shifts for $\left[\left(\eta^{6} \text {-tha }\right) \mathrm{Ru}(\mathrm{en})(\mathrm{Cl})\right]^{+}(\mathbf{1})$ and bound fragment $\left\{\left(\eta^{6} \text {-tha)Ru(en) }\right\}^{2+}\left(\mathbf{1}^{\prime}\right)\right.$ in the $1.1: 1 \mathbf{1} / \mathbf{I I}$ reaction product $\mathbf{1}^{\prime}-\mathbf{I I}$, in Ru-tha-9EtG (1'-9EtG) $)^{a, b}$ and Ru-tha-5'GMP (1'-GMP) adducts, $\mathbf{1}^{a}$,

\begin{tabular}{|c|c|c|c|c|c|c|c|c|}
\hline Complex & \multicolumn{8}{|l|}{$\delta\left({ }^{1} \mathrm{H}\right)(\Delta \delta)$} \\
\hline 1 & $2.23 / 2.43$ & $3.60 / 3.71$ & 5.50 & 5.61 & $6.19 / 6.29$ & 2.62 & 3.18 & 5.75 \\
\hline $\mathbf{1}^{\prime}-9 \mathrm{EtG}^{b f}$ & $2.07 / 2.40(-0.16)^{h}$ & na & $5.85(0.35)^{h}$ & $6.24(0.63)^{h}$ & na & $2.55(-0.07)^{h}$ & 3.20 & $5.66(-0.09)^{h}$ \\
\hline $\mathbf{1}^{\prime}-\mathrm{GMP}^{b, g}$ & $2.10 / 2.40(-0.13)^{i}$ & na & $6.16(0.66)^{i}$ & $6.16(0.55)^{i}$ & na & $3.12(0.50)^{i}$ & $4.01(0.83)^{i}$ & $5.65(-0.10)^{i}$ \\
\hline
\end{tabular}

${ }^{a}$ For atom labels, see Fig. 1 and Scheme $1 .{ }^{b}$ Ref. $28 .{ }^{c} \Delta \delta=\delta\left(\mathbf{1}^{\prime}-\mathbf{I I}\right)-\delta(\mathbf{1})(\geq 0.04 \mathrm{ppm}) .{ }^{d}$ This assignment is based on a NOESY experiment. ${ }^{e}$ At 283 $\mathrm{K} .{ }^{f}$ At $339 \mathrm{~K} .{ }^{g}$ At $318 \mathrm{~K} .{ }^{h} \Delta \delta=\delta\left(\mathbf{1}^{\prime}-9 \mathrm{EtG}\right)-\delta(\mathbf{1})(\geq 0.04 \mathrm{ppm}) .{ }^{i} \Delta \delta=\delta\left(\mathbf{1}^{\prime}-\mathrm{GMP}\right)-\delta(\mathbf{1})(\geq 0.04 \mathrm{ppm})$.

6.3-6.7 ppm (NHu-1', $\mathbf{1}^{\prime}$ is the bound complex $\mathbf{1},\left\{\left(\eta^{6}-\right.\right.$ tha $)-$ $\mathrm{Ru}(\mathrm{en})\}^{2+}$ ), Fig. S1B $\dagger$ ). Two imino ${ }^{1} \mathrm{H}$ NMR resonances were shifted to low-field by +0.04 ppm $\left(\mathrm{G}^{3 *}\right.$, mono-ruthenated $\mathrm{G}^{3}$ base) and $+0.14 \mathrm{ppm}\left(\mathrm{G}^{9}\right)$, and two imino ${ }^{1} \mathrm{H}$ resonances were shifted to high-field by $-0.07 \mathrm{ppm}\left(\mathrm{G}^{6 *}\right.$, mono-ruthenated $\mathrm{G}^{6}$ base) and $-0.04 \mathrm{ppm}\left(\mathrm{G}^{12}\right)$, relative to the free duplex II (Figs. S1 and S2, Tables S3, S4 and S2†). Reaction of the second mol equiv. of $\mathbf{1}$ with the mono-ruthenated duplexes resulted in a notable increase in intensities of the new peaks, especially $\mathrm{G}^{*} \mathrm{H} 8$ (near $8.5 \mathrm{ppm}$ ), $\mathrm{NHu}-\mathbf{1}^{\prime}$ (6.3-6.7 ppm), $\mathrm{H} 5$ and $\mathrm{H}^{\prime}$ resonances; the intensities of imino and $\mathrm{H} 8, \mathrm{H} 6$ resonances of free II all decreased (Fig. S1C $\dagger$ ). Reaction of the third mol equiv. of 1 with the di-ruthenated duplexes resulted in an increase in the intensities of new peaks, e.g. at $8.8 \mathrm{ppm}$ (Fig. S1D $\dagger$ ). The resonances of $\mathrm{CH} 5, \mathrm{CH} 6, \mathrm{H}^{\prime}$ and $\mathrm{G}^{*} \mathrm{H} 8$ moved to low field by up to $+0.3 \mathrm{ppm}$, and the peaks for imino protons almost disappeared.

\section{D $\left[{ }^{1} \mathrm{H},{ }^{1} \mathrm{H}\right]$ TOCSY NMR of $1.1: 1,2: 1$ and $3: 1$ 1/II reactions}

The 2D TOCSY NMR spectrum of the $1.1: 1$ 1/II reaction mixture clearly showed the existence of cross-peaks for the two mono-ruthenated duplexes, as seen for example in the aromatic region in Fig. 3B. Two sets of $\mathrm{H} 5-\mathrm{H} 6$ cross-peaks were detected for $\mathrm{C}^{4}, \mathrm{C}^{5}, \mathrm{C}^{7}$ and $\mathrm{C}^{10}$ residues. The proportions of Ru-IIa and $\mathrm{Ru}-\mathrm{II} b$ at $283 \mathrm{~K}$ were determined by integration of the TOCSY cross-peak volumes of $\mathrm{C}^{4}-\mathrm{H} 5 / \mathrm{C}^{4}-\mathrm{H} 6$ of Ru-IIa, and $\mathrm{C}^{5}-\mathrm{H} 5 / \mathrm{C}^{5}-\mathrm{H} 6$ of Ru-IIb, and the HPLC peak areas for I-Ru-G $\mathbf{G}^{3}$ and $\mathbf{I}-\mathrm{Ru}-\mathrm{G}^{6}$ (see Fig. 2d). This gave a Ru-IIa : Ru-IIb ratio of $2: 1( \pm 10 \%)$. Other species account for less than $10 \%$ of the total DNA. The 2D TOCSY NMR spectrum of the $2: 1$ 1/II reaction mixture shows that peaks for other new species are present but not all can be assigned due to the complexity of the spectrum (Fig. 3C). It was notable that the intensities of the $\mathrm{CH} 5-\mathrm{CH} 6$ cross-peaks for $\mathrm{C}^{5} / \mathrm{C}^{11}$ residues of free II decreased remarkably, but those of the CH5-CH6 cross-peaks for $\mathrm{C}^{1 \prime}, \mathrm{C}^{4 \prime}$ and $\mathrm{C}^{51}$ residues of the ruthenated species increased markedly. The 2D TOCSY NMR spectrum of the $3: 1 \mathbf{1} / \mathbf{I I}$ reaction mixture shows that the $\mathrm{CH} 5-$ CH6 cross-peaks for $\mathrm{C}^{5} / \mathrm{C}^{11}$ residues of free II almost completely disappeared (Fig. 3D).

\section{D $\left[{ }^{1} \mathrm{H},{ }^{15} \mathrm{~N}\right]$ HSQC NMR of the $1.1: 1$ 1/II reaction}

These experiments allowed detection of NMR peaks specifically for the $\left\{\left(\eta^{6} \text {-tha }\right) \mathrm{Ru}\left({ }^{15} \mathrm{~N} \text {-en }\right)\right\}^{2+}$ fragment. These are commonly difficult to resolve in normal ${ }^{1} \mathrm{H}$ NMR experiments. One major new species was detected by $2 \mathrm{D}\left[{ }^{1} \mathrm{H},{ }^{15} \mathrm{~N}\right] \mathrm{HSQC}$ NMR analysis of the 1.1: 1 mixture of duplex II and ${ }^{15} \mathrm{~N}-1$ (the ${ }^{15} \mathrm{~N}$-en labelled complex 1) at $283 \mathrm{~K}$ in $90 \% \mathrm{H}_{2} \mathrm{O} / 10 \% \mathrm{D}_{2} \mathrm{O}$ (Fig. S3 $†$ ). Peaks were assignable to en-NHu resonances (the $\mathrm{NH}$ protons oriented

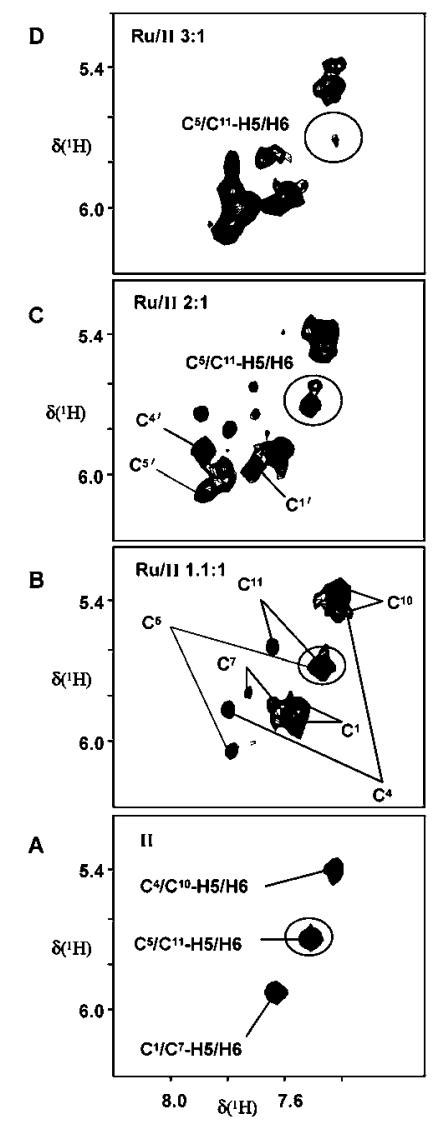

Fig. $32 \mathrm{D}\left[{ }^{1} \mathrm{H},{ }^{1} \mathrm{H}\right]$ TOCSY NMR spectrum in the cytosine H5/H6 crosspeak region for free duplex II (A), $1.1: 1$ 1/II mixture (B), $2: 1 \mathbf{1} / \mathbf{I I}$ mixture (C) and $3: 1$ 1/II mixture (D) of ruthenium complex 1 and duplex II $\left(0.34 \mathrm{mM}, 0.1 \mathrm{M} \mathrm{NaClO}_{4}\right)$ in $90 \% \mathrm{H}_{2} \mathrm{O} / 10 \% \mathrm{D}_{2} \mathrm{O}$ at $283 \mathrm{~K}$. Note that 2 sets of resonances are observed for the $\mathrm{C}^{4}, \mathrm{C}^{5}, \mathrm{C}^{7}$ and $\mathrm{C}^{10}$ residues, suggesting the presence of two mono-ruthenated products in the $1.1: 1 \mathbf{1}$ / II mixture (B). Significant changes are observed for $\mathrm{H} 5 / \mathrm{H} 6$ resonances of $\mathrm{C}^{5}$ and $\mathrm{C}^{11}$ bases when the Ru:II ratio is increased from $1.1: 1$ to $3: 1$, and the H5/H6 cross-peaks of $\mathrm{C}^{5}$ and $\mathrm{C}^{11}$ bases disappear when the $\mathrm{Ru}$ : II ratio reaches $3: 1$, suggesting that all the $\mathrm{G}^{6}$ and $\mathrm{G}^{12}$ bases are ruthenated in the $\mathbf{1} / \mathbf{I I}$ mixture $3: 1$. Assignment: $\mathrm{C}^{1 /}, \mathrm{C}^{1}-\mathrm{H} 5 / \mathrm{H} 6$ crosspeak of ruthenated species; $\mathrm{C}^{4 \prime}, \mathrm{C}^{4}-\mathrm{H} 5 / \mathrm{H} 6$ cross-peak of ruthenated species; $\mathrm{C}^{5 \prime}, \mathrm{C}^{5}-\mathrm{H} 5 / \mathrm{H} 6$ cross-peak of ruthenated species. Assignments are based on the $2 \mathrm{D}\left[{ }^{1} \mathrm{H},{ }^{1} \mathrm{H}\right]$ NOESY NMR spectrum (Tables $\mathrm{S} 2-\mathrm{S} 4 \dagger$ ) and HPLC results (Fig. 2); for DNA sequence, see Scheme 1. 
towards the coordinated arene ring, see Fig. 1 and Table $S 5 \dagger)$ of mono-ruthenated duplexes Ru-IIa and Ru-IIb $\left(\mathrm{Ru}=\left\{\left(\eta^{6}\right.\right.\right.$ tha) $\left.\mathrm{Ru}(\mathrm{en})\}^{2+}\left(\mathbf{1}^{\prime}\right)\right)$. No cross-peaks for en-NHu resonances of $\mathrm{Ru}-\mathrm{II} a$ and $\mathrm{Ru}-\mathrm{II} b$ were detectable after the equilibrium mixture had been freeze-dried and re-dissolved in $\mathrm{D}_{2} \mathrm{O}$ at $283 \mathrm{~K}$. The enNHd resonances of both Ru-IIa and Ru-IIb were not observed in either $\mathrm{H}_{2} \mathrm{O}$ or $\mathrm{D}_{2} \mathrm{O}$ solutions. In contrast, the en- $\mathrm{NHu}$ and enNHd resonances of unreacted 1 were detected in $90 \% \mathrm{H}_{2} \mathrm{O}$ (Fig. S3†). The assignments are listed in Table S5.†

\section{D $\left[{ }^{1} \mathrm{H},{ }^{31} \mathrm{P}\right] \mathrm{HSQC}$ NMR of $1.1: 11 / \mathrm{II}$ reaction}

The backbone phosphate ${ }^{31} \mathrm{P}(-0.6$ to $-1.4 \mathrm{ppm})$ to sugar ring $\mathrm{H}^{\prime}{ }^{\prime}$ (5.3-4.6 ppm) and $\mathrm{H}^{\prime}$ (4.6-4.0 ppm) HSQC connectivities for free duplex II and the $1.1: 1$ 1/II reaction are shown in Fig. 4 and the assignments are listed in Tables S3 and S4. $\dagger$ Compared to free duplex II, the ${ }^{31} \mathrm{P} / \mathrm{H} 4^{\prime}$ cross-peaks for $\mathrm{C}^{4}$ (peak e) and $\mathrm{G}^{6 *}$ (peak i) residues, ${ }^{31} \mathrm{P}_{\mathrm{n}+1} / \mathrm{H}^{\prime}{ }_{\mathrm{n}}$ cross-peaks for $\mathrm{G}^{2}-\mathrm{G}^{3 *}$ (peak d), $\mathrm{G}^{3 *}-\mathrm{C}^{4}$ (peak f) and $\mathrm{C}^{4}-\mathrm{C}^{5}$ (peak h) residues were shifted to give new peaks, but ${ }^{31} \mathrm{P} / \mathrm{H} 4^{\prime}$ cross-peaks for $\mathrm{G}^{3 *}, \mathrm{C}^{4}$ and $\mathrm{C}^{5}$ (peak g) and ${ }^{31} \mathrm{P}_{\mathrm{n}+1} / \mathrm{H} 3^{\prime}{ }_{\mathrm{n}}$ cross-peaks for $\mathrm{C}^{5}-\mathrm{G}^{6 *}$ (peak $\mathrm{j}$ ) residues were too broad to assign. Decreased intensities of ${ }^{31} \mathrm{P} / \mathrm{H} 4^{\prime}$ and ${ }^{31} \mathrm{P}_{\mathrm{n}+1} / \mathrm{H} 3^{\prime}{ }_{\mathrm{n}}$ cross-peaks were found for $\mathrm{G}^{2} / \mathrm{G}^{8}$ (peak b), $\mathrm{G}^{3} / \mathrm{G}^{9}$ (peak c), and

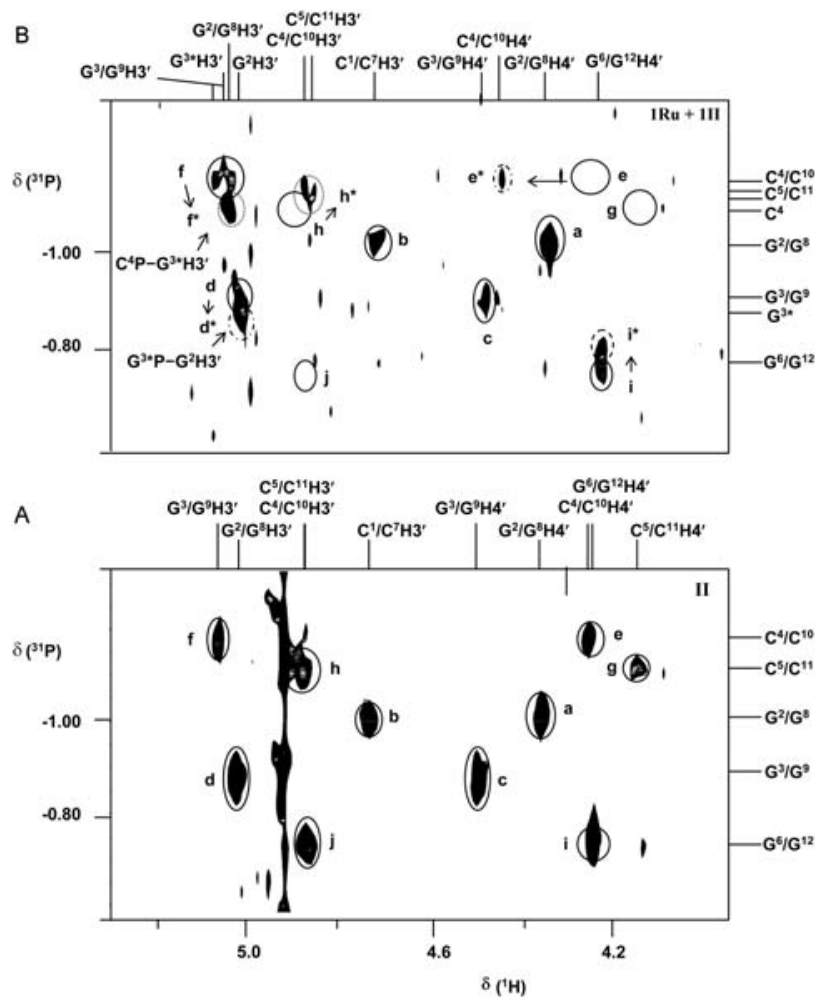

Fig. 4 2D $\left[{ }^{1} \mathrm{H},{ }^{31} \mathrm{P}\right]$ HSQC NMR spectra of (A) duplex II and (B) $1.1: 1$ 1/II mixture ( $0.34 \mathrm{mM}, 0.1 \mathrm{M} \mathrm{NaClO}_{4}$ at $283 \mathrm{~K}$, pH 7.0) in $90 \% \mathrm{H}_{2} \mathrm{O} / 10 \%$ $\mathrm{D}_{2} \mathrm{O}$, showing the backbone ${ }^{31} \mathrm{P}(-1.4$ to $-0.60 \mathrm{ppm})$ to sugar ring $\mathrm{H}^{\prime}$ (5.2-4.6 ppm) and $\mathrm{H} 4^{\prime}(4.6-4.0 \mathrm{ppm})$ connectivities. The circles indicate

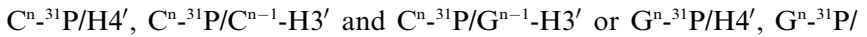
$\mathrm{G}^{\mathrm{n}-1}-\mathrm{H}^{\prime}$ and $\mathrm{G}^{\mathrm{n}-{ }^{31}} \mathrm{P} / \mathrm{C}^{\mathrm{n}-1}-\mathrm{H}^{\prime}$ assignments. Note the disappearance of cross-peaks $g$ and $\mathrm{j}$, downfield shift of cross-peaks $\mathrm{d}, \mathrm{e}, \mathrm{f}, \mathrm{h}$ and $\mathrm{i}$ to give new peaks $\mathrm{d}^{*}, \mathrm{e}^{*}, \mathrm{f}^{*}, \mathrm{~h}^{*}$ and $\mathrm{i}^{*}$, respectively, and decrease in intensity of cross-peaks c, $d$ and $f$ after ruthenation of $\mathrm{G}^{3} \mathrm{~N} 7$ (Ru-IIa) and $\mathrm{G}^{6} \mathrm{~N} 7$ (RuIIb). For DNA sequence, see Scheme 1.
$\mathrm{C}^{4} / \mathrm{C}^{10}$ (peak d) residues. These results are consistent with the HPLC-MS and 2D TOCSY NMR data.

\section{D $\left[{ }^{1} \mathrm{H},{ }^{1} \mathrm{H}\right],{ }^{15} \mathrm{~N}$-edited $\left[{ }^{1} \mathrm{H},{ }^{1} \mathrm{H}\right]$ NOESY NMR of products from $1.1: 1$ /II reaction}

Assignments for ${ }^{1} \mathrm{H}$ NMR peaks of mono-ruthenated duplexes $\mathrm{Ru}-\mathrm{II} a$ and $\mathrm{Ru}-\mathrm{II} b$ in the spectra of the $1.1: 1 \mathbf{1} / \mathbf{I I}$ reaction are listed in Tables 1, S3 and $\mathrm{S} 4, \dagger$ and intermolecular NOEs in Tables S6 and S7. $\uparrow$ For Ru-IIa, a large low-field shift of the $\mathrm{G}^{3} \mathrm{H} 8$ resonance was observed, as was also the case for $\mathrm{H} 8$ of the neighbouring $\mathrm{G}^{2}$ base and $\mathrm{H} 5$ and $\mathrm{H} 6$ of the neighbouring $\mathrm{C}^{4}$ base, relative to free duplex II (Fig. S4 and Tables S2 and S3†). The largest changes in deoxyribose $\mathrm{H}^{\prime}$ chemical shifts occur for $\mathrm{G}^{3 *}, \mathrm{G}^{2}$ and $\mathrm{C}^{5}$ residues, with the smallest changes for the neighbouring $\mathrm{C}^{4}$ and $\mathrm{C}^{10}$ residues (Fig. $\mathrm{S} 4$ and Table $\mathrm{S} 3 \dagger$ ). NOE cross-peaks were found between $\mathrm{G}^{3 *} \mathrm{H} 8$ and $\mathbf{1}^{\prime}$-en-NHd, $\mathbf{1}^{\prime}$-en$\mathrm{NHu}, \mathrm{H} 2,3, \mathrm{H} 1,4$ and $\mathrm{H} 9,10$ protons, between $\mathrm{G}^{3 *} \mathrm{H}^{\prime}, \mathrm{G}^{3 *} \mathrm{H}^{\prime} /$ $\mathrm{H} 2^{\prime \prime}$ and $\mathbf{1}^{\prime}-\mathrm{H} 9,10$ and $\mathrm{H} 1,4$ protons, between $\mathrm{C}^{4}-\mathrm{H} 5^{\prime}, \mathrm{C}^{4}-\mathrm{H} 6$ and $\mathbf{1}^{\prime}-\mathrm{H} 9,10$ and $\mathrm{H} 1,4$ protons, and between $\mathrm{C}^{4}-\mathrm{H}^{\prime}$ and $\mathbf{1}^{\prime}-\mathrm{H} 9,10$, $\mathrm{H} 5,8$ protons (Figs. 5, S6 and Table S6 $\dagger$ ). NOE cross-peaks were also found between protons of bases $\mathrm{G}^{9}, \mathrm{G}^{2}$ and $\mathrm{C}^{10}$ and $\mathbf{1}^{\prime}$. In particular, NOE cross-peaks were observed between $\mathrm{G}^{9} \mathrm{H} 2^{\prime \prime}, \mathrm{C}^{10}$ $\mathrm{H}^{\prime}$ and $\mathbf{1}^{\prime}-\mathrm{H} 6,7$ (Figs. 5, S6 and Table S6†). Sequential connectivities for base-to-sugar ${ }^{1} \mathrm{H}$ NMR resonances were obtained, but those in the $\mathrm{G}^{2}-\mathrm{C}^{3 *}, \mathrm{G}^{3 *}-\mathrm{C}^{4}$ and $\mathrm{G}^{9}-\mathrm{C}^{10}$ steps were extremely weak or absent. The interruption or weakening of NOE connectivities between sequential DNA nucleotides is consistent with the binding of $\left\{\left(\eta^{6} \text {-tha }\right) \mathrm{Ru}(\mathrm{en})\right\}^{2+}\left(\mathbf{1}^{\prime}\right)$ at $\mathrm{G}^{3 *}$ in the adduct Ru-IIa.

For adduct Ru-IIb, large low-field shifts were observed for the $\mathrm{G}^{6 *} \mathrm{H} 8$ resonance and for $\mathrm{H} 5$ and $\mathrm{H} 6$ resonances of the neighbouring $\mathrm{C}^{5}$ residue (Fig. S5 and Tables $\mathrm{S} 2$ and $\mathrm{S} 4 \uparrow$ ). The H6 resonance of $\mathrm{C}^{7}$ in the complementary strand, which is paired with $\mathrm{G}^{6}$, shifted slightly to low field, but the $\mathrm{H} 5$ resonance shifted to high-field relative to free duplex II. The largest changes in $\mathrm{H}^{\prime}$ chemical shifts were found for $\mathrm{G}^{8}$, and for $\mathrm{C}^{7}, \mathrm{C}^{5}$, and $\mathrm{G}^{6 *}$. NOE cross-peaks were found between $\mathrm{G}^{6 *} \mathrm{H} 8$ and $\mathbf{1}^{\prime}$-en-NHd, $\mathbf{1}^{\prime}$-en $\mathrm{NHu}, \mathrm{H} 2,3, \mathrm{H} 1,4, \mathrm{H} 9,10$ and $\mathrm{H} 5,8$ protons, between $\mathrm{G}^{6 *}-\mathrm{H}^{\prime}$ and $\mathbf{1}^{\prime}-\mathrm{H} 9,10, \mathrm{H} 5,8$ and $\mathrm{H} 6,7$ protons, and between $\mathrm{G}^{6 *}-\mathrm{H} 4^{\prime}$, $\mathrm{G}^{6 *}-\mathrm{H} 5^{\prime}$ and $\mathbf{1}^{\prime}-\mathrm{H} 9,10$ and $\mathrm{H} 5,8$ protons (Figs. 5, S6 and Table $\mathrm{S} 7 \dagger)$. NOE cross-peaks were also detected between protons of the bases $\mathrm{C}^{5}, \mathrm{G}^{8}, \mathrm{C}^{7}$ and bound fragment $\mathbf{1}^{\prime}$ (Figs. 5, S6 and Table $\mathrm{S} 7 \dagger)$. Particularly of note were cross-peaks observed between $\mathrm{C}^{7}$ $\mathrm{H} 2^{\prime}$ and $\mathbf{1}^{\prime}-\mathrm{H} 6,7, \mathrm{C}^{7}-\mathrm{H} 2^{\prime \prime}$ and $\mathbf{1}^{\prime}-\mathrm{H} 5,8$. Sequential base-to-sugar connectivities were obtained, but those in the $\mathrm{C}^{4}-\mathrm{C}^{5}, \mathrm{C}^{5}-\mathrm{G}^{6 *}$ and $\mathrm{C}^{7}-\mathrm{G}^{8}$ steps were extremely weak or absent. The interruption or weakening of NOE connectivities between sequential DNA nucleotides is consistent with the binding of $\mathbf{1}^{\prime}$ at $G^{6 *}$ in the adduct Ru-IIb.

Only one set of signals was observed for the bound fragment $\left\{\left(\eta^{6} \text {-tha }\right) \mathrm{Ru}(\mathrm{en})\right\}^{2+}\left(\mathbf{1}^{\prime}\right)$ in the two ruthenated duplexes Ru-IIa and Ru-IIb (Figs. 5, S6† and Table 1). Compared to the unbound chloro form of $\mathbf{1}$, peaks for $\mathbf{1}^{\prime}-\mathrm{H} 1 / \mathrm{H} 4$ and $\mathrm{H} 2 / \mathrm{H} 3$ of the coordinated arene (see Fig. 1 for labelling) were shifted to low-field, the largest shift being for $\mathbf{1}^{\prime}-\mathrm{H} 1 / \mathrm{H} 4$ (Table 1). Peaks for $\mathbf{1}^{\prime}-\mathrm{H} 9 / \mathrm{H} 10$, $\mathrm{H} 5 / \mathrm{H} 8$ and $\mathrm{H} 6 / \mathrm{H} 7$ of the non-coordinated rings were shifted to low-field by $+1.00,+0.12$ and $+0.09 \mathrm{ppm}$, respectively, the largest shift being for $\mathbf{1}^{\prime}-\mathrm{H} 9 / \mathrm{H} 10(\triangle \delta=+1.00 \mathrm{ppm})$. Two sets of slightly 


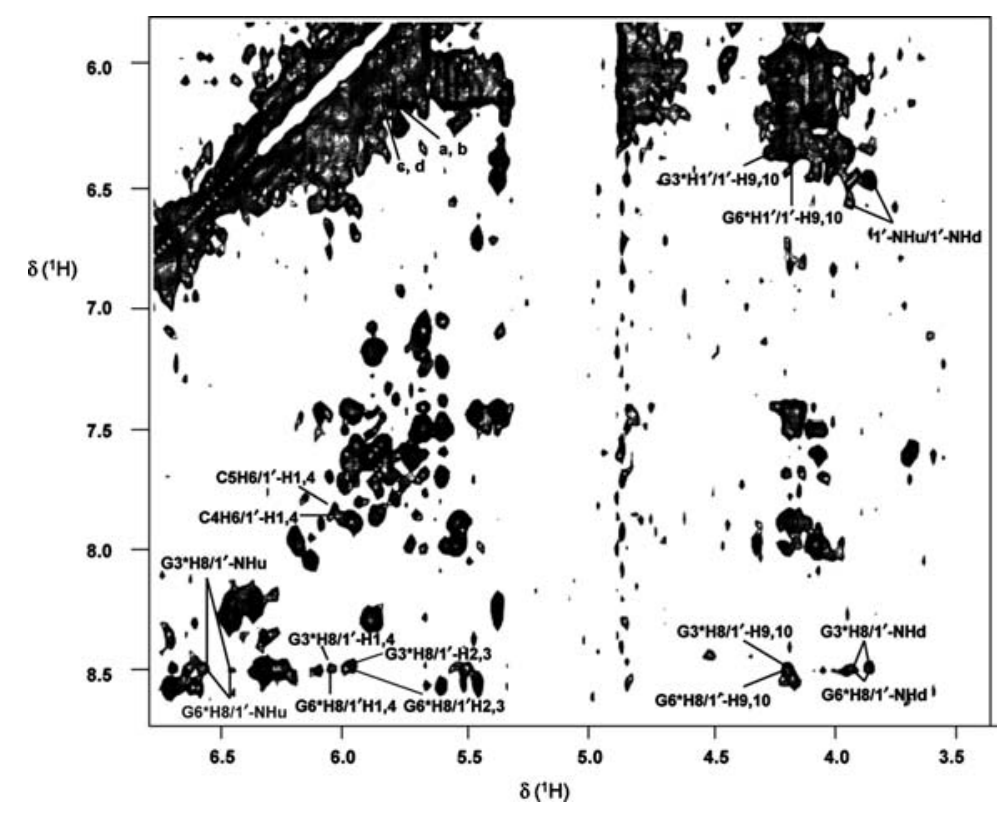

Fig. 5 Part of the $2 \mathrm{D}\left[{ }^{1} \mathrm{H},{ }^{1} \mathrm{H}\right]$ NOESY NMR spectrum of the $1: 1$ equilibrium mixture of duplex II and complex $\mathbf{1}\left(0.34 \mathrm{mM}, 0.1 \mathrm{M} \mathrm{NaClO}{ }_{4}, 90 \% \mathrm{H}_{2} \mathrm{O} /\right.$ $10 \% \mathrm{D}_{2} \mathrm{O}$ at $283 \mathrm{~K}$, pH 7.0, mixing time $400 \mathrm{~ms}$ ). Cross-peaks: a, $\mathrm{G}^{9} \mathrm{H} \mathbf{1}^{\prime} / \mathbf{1}^{\prime}-\mathrm{H} 6,7 ;$ b; $\mathrm{C}^{10} \mathrm{H1}^{\prime} / \mathbf{1}^{\prime}-\mathrm{H} 6,7 ; \mathrm{c}, \mathrm{G}^{8} \mathrm{H} \mathbf{1}^{\prime} / \mathbf{1}^{\prime}-\mathrm{H} 6,7 ; \mathrm{d}, \mathrm{C}^{7} \mathrm{H} \mathbf{1}^{\prime} / \mathbf{1}^{\prime}-\mathrm{H} 6,7$. The observed intermolecular $\left\{\left(\eta^{6} \text {-tha) Ru(en) }\right\}^{2+}\right.$-II cross-peaks from mono-ruthenated product II-Ru-G ${ }^{3}$ are: $\mathrm{G}^{3 *} \mathrm{H} 8 / \mathbf{1}^{\prime}$-enNHu, $\mathrm{G}^{3 *} \mathrm{H} 8 / \mathbf{1}^{\prime}$-enNHd, $\mathrm{G}^{3 *} \mathrm{H} 8 / \mathbf{1}^{\prime}$-H $\mathrm{H} / 10$, $\mathrm{G}^{3 *} \mathrm{H} 8 / \mathbf{1}^{\prime}-\mathrm{H} 1,4, \mathrm{G}^{3 *} \mathrm{H1}^{\prime} / \mathbf{1}^{\prime}-\mathrm{H} 9 / 10, \mathrm{G}^{3 *} \mathrm{H1}^{\prime} / \mathbf{1}^{\prime}-\mathrm{H} 1,4, \mathrm{C}^{4} \mathrm{H} 6 / \mathbf{1}^{\prime}-\mathrm{H} 1,4, \mathrm{C}^{4} \mathrm{H} 6 / \mathbf{1}^{\prime}-\mathrm{H} 9,10, \mathrm{C}^{4} \mathrm{H} 5 / \mathbf{1}^{\prime}-\mathrm{H} 9,10, \mathrm{G}^{9} \mathrm{H} \mathbf{1}^{\prime} / \mathbf{1}^{\prime}-\mathrm{H} 6,7, \mathrm{C}^{10} \mathrm{H} \mathbf{1}^{\prime} / \mathbf{1}^{\prime}-\mathrm{H} 6,7$; and from II-Ru-G ${ }^{6}$ are: $\mathrm{G}^{6 *} \mathrm{H} 8 / \mathbf{1}^{\prime}$-enNHu, G ${ }^{6 *} \mathrm{H} 8 / \mathbf{1}^{\prime}$-enNHd, G ${ }^{6 *} \mathrm{H} 8 / \mathbf{1}^{\prime}-\mathrm{H} 9 / 10, \mathrm{G}^{6 *} \mathrm{H} 8 / \mathbf{1}^{\prime}-\mathrm{H} 1,4, \mathrm{G}^{6 *} \mathrm{H} \mathbf{1}^{\prime} / \mathbf{1}^{\prime}-\mathrm{H} 9 / 10, \mathrm{C}^{5} \mathrm{H} 6 / \mathbf{1}^{\prime}-\mathrm{H} 1,4, \mathrm{G}^{8} \mathrm{H} \mathbf{1}^{\prime} / \mathbf{1}^{\prime}-\mathrm{H} 6,7, \mathrm{C}^{7} \mathrm{H} \mathbf{1}^{\prime} / \mathbf{1}^{\prime}-\mathrm{H} 6,7 . \mathrm{Cross}^{-}$ peaks within the ruthenated guanine residues $G^{3 *}$ or $G^{6 *}$, and within the bound ruthenium complex $\mathbf{1}^{\prime}$ are also indicated. Labels: $\mathbf{1}^{\prime}=\left\{\left(\eta^{6}\right.\right.$-tha)$\mathrm{Ru}(\mathrm{en})\}^{2+}$; ruthenated guanines are marked with asterisks. For NMR chemical shifts, see Tables S2-S4, $\dagger$ and for atom labels, see Fig. 1 .

low-field-shifted or unchanged signals for $\mathbf{1}^{\prime}$-en $\mathrm{CH}_{2}$ of both $\mathrm{Ru}$ IIa and Ru-IIb were detected. Two sets of signals for both $\mathbf{1}^{\prime}$-enNHd and en-NHu protons of Ru-IIa and Ru-IIb were observed, and the peaks for $\mathbf{1}^{\prime}$-NHd and $\mathrm{NHu}$ were shifted to low-field, the largest shift being for $\mathbf{1}^{\prime}$-NHu. One set of signals from unreacted ruthenium complex 1 was observed in the $1.1: 1$ 1/II reaction mixture (Fig. S7† and Table 1). These results are consistent with ROESY experiments (data not shown).

\section{Discussion}

Complex 1 selectively ruthenates guanine bases in single strand DNA I or duplex II (Fig. 2a-c) with a similar pattern to that observed for the biphenyl (bip) and $p$-cymene (cym) complexes. ${ }^{22}$ Complex $\mathbf{1}$ is as reactive towards duplex II as the Ru-bip complex, and much more reactive than the Ru-cym complex. This pattern of reactivity was observed previously with calf thymus DNA, for which $t_{50 \%}$ values of $10 \mathrm{~min}, 10 \mathrm{~min}$ and $3.5 \mathrm{~h}$ for complexes 1, Ru-bip and Ru-cym, respectively, were found. ${ }^{26}$

Precipitation of adducts was observed when $>1$ mol equiv. of $\mathrm{Ru}$-bip or Ru-cym complex was added to duplex II $(0.2 \mathrm{mM}){ }^{22}$ However, no such behaviour was observed in the present work. Addition of up to 3 mol equiv. of complex 1 to duplex II, even at the higher concentration of $0.3 \mathrm{mM}$, did not result in precipitation. This suggests that the nature of the arene influences intermolecular interactions. However, precipitation of adducts was observed when $>3$ mol equiv. of complex 1 was added to duplex II $(0.3 \mathrm{mM})$, and was also the case when the reaction mixture of $\mathbf{1}+$ II (3: 1) was kept at $277 \mathrm{~K}$ for long periods ( $c a$. four weeks).
Intermolecular interactions are probably also influenced by the order of occupation of the $\mathrm{Ru}$ sites and the extent of arene intercalation (for tha and bip).

\section{Determination of binding sites by NMR}

The ${ }^{31} \mathrm{P}$ chemical shift changes determined from the $2 \mathrm{D}\left[{ }^{1} \mathrm{H},{ }^{31} \mathrm{P}\right]$ HSQC NMR experiment are consistent with ruthenation at N7 of the $\mathrm{G}$ residues of the 6-mer DNA duplex II by $\mathbf{1}$. Binding of Ru-bip to the phosphate of $5^{\prime}$-GMP ${ }^{27,28}$ causes a low-field shift of the ${ }^{31} \mathrm{P}$ NMR resonance by up to $+5.11 \mathrm{ppm}$. However, the binding of Ru-bip to N7 of $5^{\prime}$-GMP, ${ }^{28} 5^{\prime}$-IMP or $5^{\prime}$-cGMP caused low-field ${ }^{31} \mathrm{P}$ NMR shifts of less than $1 \mathrm{ppm}$. Similarly, ruthenation of $5^{\prime}$-GMP by trans-[ $\left.\mathrm{RuCl}_{2}(\mathrm{DMSO})_{4}\right]$ giving $\mathrm{Ru}-$ $\mathrm{OPO}_{3}$ coordination causes a $+5.8 \mathrm{ppm}{ }^{31} \mathrm{P}$ downfield shift, ${ }^{62}$ and direct $\mathrm{Pt}-\mathrm{OPO}_{3}$ binding to IMP produces a ${ }^{31} \mathrm{P}$ downfield shift of about +3.5 ppm..$^{63}$ The formation of N7-ruthenated complexes of $5^{\prime}$-GMP and 5'-IMP, N6- or N4-ruthenated complexes of 5'AMP or $5^{\prime}$-CMP by $\left\{\mathrm{Ru}(\mathrm{III})\left(\mathrm{NH}_{3}\right)_{5}\right\}^{3+}$ gave rise to little change in ${ }^{31} \mathrm{P}$ resonances of the nucleotides. ${ }^{64}$ Therefore, it is evident that direct coordination of $\mathrm{Ru}^{\mathrm{II}}$ to a phosphate oxygen induces a ${ }^{31} \mathrm{P}$ chemical shift change of $c a$. $+5 \mathrm{ppm}$, while coordination to GN7 and no direct binding to phosphate oxygen induces a chemical shift change in the range of $0-1 \mathrm{ppm}$. In the present case, the most affected signals are assigned to the phosphate groups of residue $\mathrm{C}^{4}(\Delta \delta+0.09 \mathrm{ppm})$ and residue $\mathrm{G}^{6 *}(\Delta \delta-0.05 \mathrm{ppm})$ (Fig. 4 and Tables S3 and S4). $\dagger$ Other ${ }^{31} \mathrm{P}$ resonances are shifted by less than $0.03 \mathrm{ppm}$. Significant changes were observed for ${ }^{31} \mathrm{P}$, $\mathrm{H}^{\prime}$ and $\mathrm{H}^{\prime}$ resonances of residues $\mathrm{G}^{3 *}, \mathrm{C}^{4}, \mathrm{C}^{5}$ and $\mathrm{G}^{6 *}$; minor 
changes observed for the corresponding resonances of $\mathrm{C}^{1} / \mathrm{C}^{7}$ and $\mathrm{G}^{2} / \mathrm{G}^{8}$ further indicated that the binding site was $\mathrm{N} 7$ of $\mathrm{G}^{3 *}$ or $\mathrm{G}^{6 *}$. Selective binding to $\mathrm{N} 7$ of the $\mathrm{G}$ residues of double-stranded DNA duplex II was evident from the ${ }^{15} \mathrm{~N}$-edited $\left[{ }^{1} \mathrm{H},{ }^{1} \mathrm{H}\right] \mathrm{NOESY}$ NMR spectrum and confirmed by ${ }^{1} \mathrm{H}$ NMR chemical shift changes (Figs. 5, S6 and Tables S3 and S5 $\dagger$ ). NOE connectivities between ruthenated $\mathrm{G}^{*} \mathrm{H} 8$ and $\mathbf{1}^{\prime}$-NHu or $\mathbf{1}^{\prime}$-NHd were observed in the ${ }^{15} \mathrm{~N}$-edited $\left[{ }^{1} \mathrm{H},{ }^{1} \mathrm{H}\right] \mathrm{NOESY}$ and ${ }^{15} \mathrm{~N}$-decoupled $\left[{ }^{1} \mathrm{H},{ }^{1} \mathrm{H}\right]$ NOESY NMR spectra. Binding of 1 to 9-ethylguanine and 5'$\mathrm{GMP}^{27}$ via $\mathrm{N} 7$ causes a low-field shift of the H8 ${ }^{1} \mathrm{H}$ NMR resonance by up to $+0.6 \mathrm{ppm}$. Binding of Ru-cym and Ru-bip complexes to 6-mer single strand DNA I or duplex $\mathbf{I I}^{23}$ via $\mathrm{N} 7$ causes low-field shifts of the $\mathrm{H} 8{ }^{1} \mathrm{H}$ NMR resonance of +0.49 to $+0.66 \mathrm{ppm}$, and +0.28 to $+0.58 \mathrm{ppm}$, respectively. Similar shifts were observed for the $\mathrm{H} 8$ resonances of $\mathrm{G}$ bases in the hexamer, and allow assignment of the binding sites as $\mathrm{G}^{3 *}(\triangle \delta \mathrm{H} 8+0.59$ ppm) in Ru-IIa and $\mathrm{G}^{6 *}(\triangle \delta \mathrm{H} 8+0.46$ ppm) in $\mathrm{Ru}-\mathrm{II} b$ present in the $1.1: 1$ reaction mixture of $\mathbf{1}+$ II (Figs. S1, S4 and S5, Tables S3 and $\mathrm{S} 4 \dagger)$. With the binding fragment $\left\{\left(\eta^{6}\right.\right.$-tha $)$ $\mathrm{Ru}(\mathrm{en})\}^{2+}\left(\mathbf{1}^{\prime}\right)$, the mono-ruthenated duplex Ru-IIa is assigned as II-Ru-G $\mathbf{G}^{3}\left(\mathbf{1}^{\prime}\right)$, Ru-IIb as II-Ru-G $\mathrm{G}^{6}\left(\mathbf{1}^{\prime}\right)$ (for DNA sequence, see Scheme 1).

The ruthenation of duplex II by complex 1 mainly caused lowfield shifts of imino proton resonances of $G$ residues $G^{3 *}$ and $G^{9}$ in II-Ru- $\mathrm{G}^{3}\left(\mathbf{1}^{\prime}\right)$, but high field shifts of imino proton resonances of $\mathrm{G}$ residues $\mathrm{G}^{6 *}$ and $\mathrm{G}^{12}$ in II-Ru-G $\mathrm{G}^{6}\left(\mathbf{1}^{\prime}\right)$ (Fig. S2 and Tables S3 and $\mathrm{S} 4 \dagger$ ). In contrast, the imino proton resonances of the monointercalated duplexes and di-intercalated duplex ruthenated with Ru-bip are broad and weak, implying that the base-pairs are disrupted in the duplex with an increase in dynamic mobility of the bases. ${ }^{23}$ High-field shifts of imino proton resonances were found for mono-ruthenated species in the $1: 1$ reaction mixture of Ru-cym complex + II, and platination of the 14-mer duplex d(TATGTACCATGTAT)/d(ATACATGGTACATA) also causes high field shifts of $\mathrm{G}$ imino proton resonances. ${ }^{23,59}$

Structural perturbations induced by ruthenation with complex 1 are larger than those observed for Ru-bip and Ru-cym complexes, ${ }^{23}$ and are localized to within a few $( \pm 2)$ base-pairs of the ruthenation site in all cases for complex $\mathbf{1}$, while only the two adjacent bases $\left(\mathrm{C}^{4}\right.$ and $\mathrm{C}^{10}$ or $\mathrm{C}^{5}$ and $\left.\mathrm{C}^{7}\right)$ are affected by ruthenation at $\mathrm{G}^{3 *}$ or $\mathrm{G}^{6 *}$ in all cases for Ru-bip and $\mathrm{Ru}$-cym adducts. Not only were large low-field shifts of the $\mathrm{H} 5$ and $\mathrm{H} 6$ resonances observed for $\mathrm{C}^{4}$ in II-Ru-G ${ }^{3}\left(\mathbf{1}^{\prime}\right)$ and $\mathrm{C}^{5}$ in II-Ru- $\mathrm{G}^{6}\left(\mathbf{1}^{\prime}\right)$, but also for $\mathrm{H}^{\prime}$ of $\mathrm{G}^{2}, \mathrm{G}^{3}, \mathrm{C}^{4}, \mathrm{C}^{5}$ and $\mathrm{C}^{11}$ in II-Ru-G $\mathrm{G}^{3}\left(\mathbf{1}^{\prime}\right)$, and of $\mathrm{C}^{5}, \mathrm{C}^{7}$ and $\mathrm{G}^{8}$ in II-Ru-G $\mathrm{G}^{6}\left(\mathbf{1}^{\prime}\right)$ (Tables S3 and $\mathrm{S} 4 \dagger$ ).

\section{Intercalation}

Literature reports show that intercalation into DNA base pairs can often be recognised by distinctive features, ${ }^{19,22,23,49,54,61,65}$ including (a) upfield ${ }^{1} \mathrm{H}$ NMR shifts of resonances of the intercalator; (b) NOE cross-peaks between protons of the intercalator and DNA bases at sites of intercalation; (c) the interruption or weakening of NOE connectivities between sequential DNA nucleotides; (d) the absence or weakening of the correlation peaks of $\mathrm{H}^{\prime}{ }_{\mathrm{n}}^{-}{ }^{31} \mathrm{P}_{\mathrm{n}+1}$ and $\mathrm{H} 3^{\prime}{ }_{\mathrm{n}}{ }^{-31} \mathrm{P}_{\mathrm{n}}$ at sites of intercalation steps and the large chemical shift perturbations at the intercalation steps; and (e) the weakening of the strength of H-bonding between en-NH and GO6 in the case when the ruthenium complex Ru-bip with an extended arene ring system was involved. ${ }^{22,23}$

It is notable that no large high-field shifts of proton resonances of $\mathbf{1}^{\prime}$ were detected, but large low-field shifts up to $+1.00 \mathrm{ppm}$ were observed for protons $\mathrm{H} 9,10, \mathrm{H} 5,8$ and $\mathrm{H} 6,7$ of rings $\mathrm{B}$ and $\mathrm{C}$ in the mono-ruthenated duplexes II-Ru-G ${ }^{3}\left(\mathbf{1}^{\prime}\right)$ and II-Ru$\mathrm{G}^{6}\left(\mathbf{1}^{\prime}\right)$ (Table 1). These shifts are inconsistent with shielding effects from the ring-currents of nucleobases which form a sandwich with the intercalated non-coordinated rings of bound $\mathbf{1}^{\prime}$, and so do not provide evidence for intercalative binding. ${ }^{19,49,54,65}$ For example, upfield shifts of between -0.4 and $-1.0 \mathrm{ppm}$ have been reported for Ru-bip intercalated into 6-mer or 14-mer duplex DNA, ${ }^{22,23}$ and upfield shifts of -0.1 to $-1.0 \mathrm{ppm}$ for the intercalated dap (1,12-diazaperylene) ligand of the dirhodium(II) carboxylate complex $\left[\mathrm{Rh}_{2}\right.$ (dap) $\left(\mathrm{CH}_{3-}\right.$ $\mathrm{COO})_{3}\left(\mathrm{CH}_{3} \mathrm{OH}\right)_{3}$ ] into a 12-mer duplex DNA. ${ }^{19}$ Such large lowfield shifts of the bulky tha intercalator have not been observed for other bulky intercalators, for example, large high-field shifts have been observed for bulky intercalated cholesterol groups. ${ }^{44}$ However, similar large low-field shifts for proton resonances of $\mathbf{1}^{\prime}-9 \mathrm{EtG}$ were found for the adduct $\left[\left(\eta^{6}\right.\right.$-tha)Ru(en)(9EtG)]; ${ }^{28}$ the $\mathrm{H} 5,8$ and H6,7 resonances slightly shifted to high-field, but the $\mathrm{H} 9,10$ resonances remained unchanged. In the case of $\left[\left(\eta^{6}-\right.\right.$ tha)Ru(en)(5'-GMP)] (1'-GMP) ${ }^{28}$ H9,10 and H5,8 resonances are shifted to low-field by +0.83 and $+0.50 \mathrm{ppm}$, respectively, and the $\mathrm{H} 6,7$ resonances shifted to high-field by $-0.10 \mathrm{ppm}$. In the present case of the mono-ruthenated duplexes II-Ru-G ${ }^{3}\left(\mathbf{1}^{\prime}\right)$ and II-Ru-G ${ }^{6}\left(\mathbf{1}^{\prime}\right), \mathrm{H} 9,10, \mathrm{H} 5,8$ and H6,7 resonances shifted to lowfield by $+1.00,+0.12$ and +0.09 ppm, respectively. Thus it is reasonable that the resonances of intercalated non-aromatic rings $\mathrm{B}$ and $\mathrm{C}$ of tha in the mono-ruthenated duplexes II-Ru$\mathrm{G}^{3}\left(\mathbf{1}^{\prime}\right)$ and II-Ru-G $\mathrm{G}^{6}\left(\mathbf{1}^{\prime}\right)$ shift to low field.

The single crystal X-ray structure of $\left(\mathbf{1}^{\prime}-\mathrm{GMP}\right)^{\mathbf{2 8}}$ shows that ring $\mathrm{C}$ of $\mathbf{1}^{\prime}$ is tilted towards the purine by $27.8^{\circ}$ and lies directly over the purine base, indicative of strong intramolecular $\pi-\pi$ stacking between ring $\mathrm{C}$ and the purine ring with a centroid-centroid separation of $3.45 \AA$ and dihedral angle of $3.3^{\circ}$. Intercalation of the non-coordinated rings of $\mathbf{1}^{\prime}$ into the DNA duplex is also consistent with circular and linear dichroism data. ${ }^{26,29}$ Due to excessive resonance broadening, the resonances for protons that intercalate between purine rings are difficult to assign. Weak to intermediate intensity NOE cross-peaks were found not only between the rings of bound $\mathbf{1}^{\prime}$ and $\mathrm{H}^{\prime}$ or $\mathrm{H} 8$ protons of $\mathrm{G}^{3 *}$ or $\mathrm{C}^{4}$ in II-Ru-G $\mathrm{G}^{3}\left(\mathbf{1}^{\prime}\right)$, but also between the rings of $\mathbf{1}^{\prime}$ and $\mathrm{G}^{9}$ and $\mathrm{C}^{10}$ (Figs. 5, S6 and Table S6 $†$ ). This can happen if the intercalation occurs not only at the $\mathrm{G}^{3} \mathrm{pC}^{4}$ base step, but also at the $\mathrm{G}^{9} \mathrm{pC}^{10}$ base step. The intermediate intensity cross-peaks observed between $\mathrm{G}^{9} \mathrm{H} 2^{\prime \prime}$ or $\mathrm{C}^{10} \mathrm{H} 1^{\prime}$ and $\mathbf{1}^{\prime}-\mathrm{H} 6,7$ protons, indicate that the extended rings of $\mathbf{1}^{\prime}$ intercalate deeply and are located between the middle of $\mathrm{G}^{9}$ and $\mathrm{C}^{10}$ bases. Analogous NOE cross-peaks between the rings of bound $\mathbf{1}^{\prime}$ and $\mathrm{H}^{\prime}, \mathrm{H} 8, \mathrm{H} 2^{\prime}$ and $\mathrm{H} 2^{\prime \prime}$ of $\mathrm{G}^{6 *}$ in II-Ru-G $\mathrm{G}^{6}\left(\mathbf{1}^{\prime}\right)$, and also between rings of $\mathbf{1}^{\prime}$ and $\mathrm{C}^{5}, \mathrm{C}^{7}$ and $\mathrm{G}^{8}$ were detected, indicating that intercalation occurs between $\mathrm{G}^{6 *}$ and $\mathrm{C}^{5}$, and between $\mathrm{G}^{8}$ and $\mathrm{C}^{7}$ as well (Figs. 5 and $\mathrm{S} 6$, and Table $\mathrm{S} 7 \dagger$ ). The intermediate intensity cross-peaks observed between $\mathrm{G}^{6}$ or $\mathrm{C}^{5}$ and $\mathbf{1}^{\prime}$-H1,4 protons, indicate that the coordinated arene ring of $\mathbf{1}^{\prime}$ is located between the middle of $\mathrm{G}^{6}$ and $\mathrm{C}^{5}$ bases. Additionally, intermediate intensity cross-peaks observed between $\mathrm{C}^{7} \mathrm{H} 2^{\prime}$ and $\mathbf{1}^{\prime}$-H6,7 and $\mathrm{C}^{7} \mathrm{H} 2^{\prime \prime}$ and $\mathbf{1}^{\prime}-\mathrm{H} 5,8$ protons indicate that the extended rings of 
$\mathbf{1}^{\prime}$ intercalate deeply and are located near to the $\mathrm{C}^{7}$ base. The interruption of NOE connectivity pathways between the corresponding base pairs $\left(\mathrm{G}^{2}-\mathrm{C}^{3 *}, \mathrm{G}^{3 *}-\mathrm{C}^{4}\right.$ and $\mathrm{G}^{9}-\mathrm{C}^{10}$ steps in II-Ru$\mathrm{G}^{3}\left(\mathbf{1}^{\prime}\right)$, and $\mathrm{C}^{4}-\mathrm{C}^{5}, \mathrm{C}^{5}-\mathrm{G}^{6 *}$ and $\mathrm{C}^{7}-\mathrm{G}^{8}$ steps II-Ru-G $\left(\mathbf{1}^{\prime}\right)$ ) is consistent with these intercalation sites.

The absence of the $\mathrm{H}^{\prime}{ }_{n}-\mathrm{P}_{\mathrm{n}+1}$ cross-peaks linking the $\mathrm{C}^{5}-\mathrm{G}^{6 *}$ step and the $\mathrm{H}^{\prime}-\mathrm{P}$ cross-peaks of $\mathrm{G}^{3 *}, \mathrm{C}^{4}$ and $\mathrm{C}^{5}$, the low field shifts for $\mathrm{H}^{\prime}{ }_{n}{ }^{-} \mathrm{P}_{\mathrm{n}+1}$ cross-peaks linking $\mathrm{G}^{2}-\mathrm{G}^{3 *}, \mathrm{C}^{4}-\mathrm{C}^{5}$ and $\mathrm{G}^{3 *}$ $\mathrm{C}^{4}$, and for $\mathrm{H}^{\prime}-\mathrm{P}$ cross-peaks of $\mathrm{C}^{4} / \mathrm{C}^{10}$ and $\mathrm{G}^{6}$, and the large chemical shift perturbations at the $\mathrm{G}^{2}-\mathrm{G}^{3 *}$ and $\mathrm{C}^{5}-\mathrm{G}^{6 *}$ steps, together indicate that the intercalation occurs between $\mathrm{G}^{3} \mathrm{pC}^{4}$ or $\mathrm{C}^{5} \mathrm{pG}^{6}$ base steps (Fig. 4). ${ }^{62}$ Previous work has shown that the intercalation sites of the non-coordinated phenyl ring of $\mathrm{Ru}$-bip in mono-ruthenated duplexes ${ }^{4 c}$ are also between $\mathrm{G}^{3} \mathrm{pC}^{4}$ or $\mathrm{C}^{5} \mathrm{pG}^{6}$ base steps.

No cross-peaks for en-NHu resonances of Ru-IIa and Ru-IIb were detected after the $1.1: 1 \mathbf{1} / \mathbf{I I}$ reaction mixture had been freeze-dried and re-dissolved in $\mathrm{D}_{2} \mathrm{O}$. This suggests that the hydrogen bond between $\mathrm{G}^{*} \mathrm{O} 6$ and en- $\mathrm{NH}$ of $\mathbf{1}^{\prime}$ is weakened (Fig. S3 and Table S5 $†$ ), which is consistent with intercalation of the non-coordinated rings of $\mathbf{1}^{\prime}$ into duplex DNA II. Similarly weakened hydrogen bonds were also observed when the biphenyl ring of Ru-bip intercalates into the hexamer duplex. ${ }^{22}$ The strength of the $\mathrm{H}$-bond between $\mathrm{G}^{*} \mathrm{O} 6$ and en- $\mathrm{NH}$ is related to the decay rate of the en-NH signals when II-Ru adducts are dissolved in $99 \% \mathrm{D}_{2} \mathrm{O} .{ }^{22}$ For the non-intercalated adduct with Ru-cym, the half-life was $72 \mathrm{~h}$. However, those of the mono- and di-intercalated Ru-bip adducts were only $5 \mathrm{~h}$ and $<0.1 \mathrm{~h}$, respectively.

NMR studies show that the arene-nucleobase $\pi-\pi$ stacking of $\mathbf{1}^{\prime}$ with hexamer duplex is different from that of Ru-bip. ${ }^{22,23}$ Only a very few weak NOE contacts between protons of ring B of biphenyl and $\mathrm{H}^{\prime}$ and $\mathrm{H}_{2} / \mathrm{H}^{\prime \prime}$ protons of $\mathrm{G}^{3 *}$ or $\mathrm{C}^{4}$ of the hexamer duplex are observed. ${ }^{22}$ The protons $\mathrm{Ho}^{\prime}, \mathrm{Hp}^{\prime}$ and $\mathrm{Hm}^{\prime}$ of bound Ru-bip in the DNA duplex adducts were consistently shielded relative to free Ru-bip, consistent with base stacking of the non-coordinated ring $\mathrm{B}$ between base pair $\mathrm{G}^{3 *} \mathrm{pC}^{4}$. However, in the present case, not only were weak to intermediate intensity NOE contacts detected between protons of rings $\mathrm{B}$ and $\mathrm{C}$ of tha and protons of $\mathrm{G}^{3 *}$ and $\mathrm{C}^{4}$ or $\mathrm{G}^{6 *}$ and $\mathrm{C}^{5}$, but also intermediate intensity NOE contacts were detected between protons of ring $\mathrm{C}$ of tha and protons of $\mathrm{G}^{9}$ and $\mathrm{C}^{10}$ or $\mathrm{C}^{7}$ and $\mathrm{G}^{8}$ DNA bases which pair with $\mathrm{G}^{3 *}$ or $\mathrm{C}^{4}, \mathrm{G}^{6 *}$ or $\mathrm{C}^{5}$ in the complementary DNA strand (Fig. 5, Tables $\mathrm{S} 6$ and $\mathrm{S} 7 \dagger$ ), respectively. This indicates that rings $\mathrm{B}$ and $\mathrm{C}$ of tha are involved in a penetrative intercalation between two pairs of bases, $\mathrm{G}^{3} / \mathrm{C}^{10}: \mathrm{C}^{4} / \mathrm{G}^{9}$ or $\mathrm{G}^{6} / \mathrm{C}^{7}: \mathrm{C}^{5} / \mathrm{G}^{8}$. It is interesting that large low-field shifts, but not large high-field shifts are observed for the proton resonances of intercalated rings $\mathrm{B}$ and $\mathrm{C}$ of $\mathbf{1}^{\prime}$, indicating that the intercalative interactions between Ru-tha and Ru-bip with the DNA duplex are significantly different from one another. The ring current shifts are position-related: upfield shifts only arise when the protons are above or below the ring plane. In contrast, resonances for protons located close to the plane and beyond the confines of the ring are shifted to low field. ${ }^{66}$

\section{Modelling of II-Ru-G ${ }^{3}\left(1^{\prime}\right)$ and II-Ru-G ${ }^{6}\left(1^{\prime}\right)$}

In order to attempt to rationalize the NOE and chemical shift information gathered for II-Ru-G ${ }^{3}\left(\mathbf{1}^{\prime}\right)$ and II-Ru- $\mathrm{G}^{6}\left(\mathbf{1}^{\prime}\right)$, two

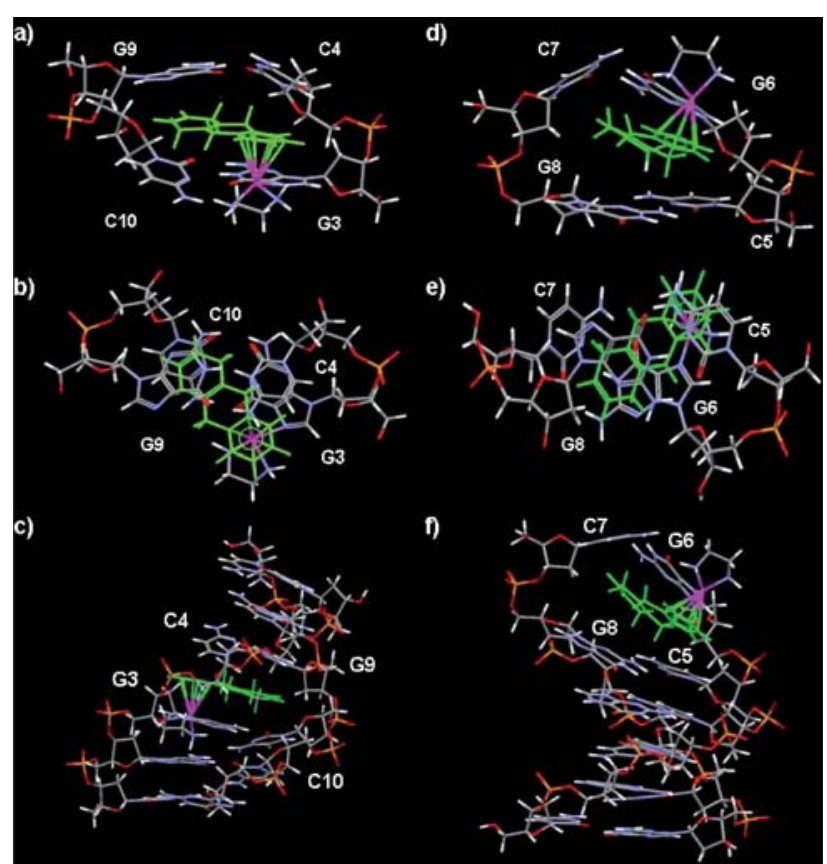

Fig. 6 Molecular models of duplex II ruthenated at N7 of $\mathrm{G}^{3}$ or N7 of $\mathrm{G}^{6}$ with $\left\{\left(\eta^{6} \text {-tha) } \mathrm{Ru}(\mathrm{en})\right\}^{2+}\right.$. (a)-(c) II-Ru-G $\mathrm{G}^{3}$ showing the intercalation of the tetrahydroanthracene ligand between $\mathrm{G}^{3} / \mathrm{C}^{10}: \mathrm{C}^{4} / \mathrm{G}^{9}$. (d)-(f) II-Ru- $\mathrm{G}^{6}$ in which the non-arene rings are intercalated between $G^{6} / C^{7}: C^{5} / G^{8}$. In each case side and top views of the intercalation site are shown as well as the whole duplex (bottom). Colour code: tha green, Ru purple, $\mathrm{P}$ yellow, O red.

molecular models were constructed in which the duplex $\mathrm{d}(\mathrm{CGGCCG})_{2}$ was ruthenated at $\mathrm{N} 7$ of $\mathrm{G}^{3}$ or $\mathrm{G}^{6}$ by $\mathbf{1}^{\prime}$, as shown in Fig. 6. The II-Ru-G $\mathbf{G}^{3}\left(\mathbf{1}^{\prime}\right)$ (Fig. 6a-c) and II-Ru-G $\mathbf{G}^{6}\left(\mathbf{1}^{\prime}\right)$ (Fig. 6df) models are mostly consistent with the NMR observations, and overwhelming evidence indicates that a penetrative interaction occurs between rings $\mathrm{B}$ and $\mathrm{C}$ of $\mathbf{1}^{\prime}$ and duplex DNA at $\mathrm{G}^{3} /$ $\mathrm{C}^{10}: \mathrm{C}^{4} / \mathrm{G}^{9}$ or $\mathrm{G}^{6} / \mathrm{C}^{7}: \mathrm{C}^{5} / \mathrm{G}^{8}$, respectively. The model also provides a useful indication of how $\mathbf{1}^{\prime}$ may lie in relation to its DNA binding site. The $\mathrm{H} 5,8$ and $\mathrm{H} 9,10$ protons of $\mathbf{1}^{\prime}$ are located above or below the ring plane and the distances between $\mathrm{H} 5,8$ or $\mathrm{H} 9,10$ protons and purine or pyrimidine rings of $\mathrm{G}$ or $\mathrm{C}$ bases are nearly $0.9 \AA$ shorter than the case of aromatic intercalators, such as Rubip. Compared to the structural findings for aromatic intercalators, both structures (II-Ru- $\mathbf{G}^{3}\left(\mathbf{1}^{\prime}\right)$ and II-Ru- $\mathrm{G}^{6}\left(\mathbf{1}^{\prime}\right)$ ) suggest distortion of bases-pair planes around the site at which the tha has penetrated and the system is likely to be highly dynamic in and around the intercalation sites. The dynamics of II-Ru- $\mathrm{G}^{6}\left(\mathbf{1}^{\prime}\right)$, in which the Ru binds to a terminal, potentially frayed nucleotide, would be expected to be significantly different compared with those for II-Ru-G $\mathbf{G}^{3}\left(\mathbf{1}^{\prime}\right)$, in which the Ru binds to the internal base.

The data imply that in both cases the tha of $\mathbf{1}^{\prime}$ in the models has swung round so that the ring system points across to the opposite strand rather than penetrating so deeply into the strand to which the $\mathrm{Ru}$ centre is attached $\left(\mathrm{G}^{3^{*}}\right.$ or $\left.\mathrm{G}^{6^{*}}\right)$. This supports the NOE contacts observed between protons of rings A and B of $\mathbf{1}^{\prime}$ and $\mathrm{H}^{\prime}$ and $\mathrm{H} 8$ or $\mathrm{H} 6$ protons of $\mathrm{G}^{3}, \mathrm{C}^{4}$ or $\mathrm{C}^{5}, \mathrm{G}^{6}$ and in particular between $\mathrm{H} 6,7$ protons of ring $\mathrm{C}$ of $\mathbf{1}^{\prime}$ and the $\mathrm{H}^{\prime}$, and $\mathrm{H} 2^{\prime}$ protons of residue $\mathrm{C}^{10}, \mathrm{G}^{9}$ or $\mathrm{G}^{8}, \mathrm{C}^{7}$ of the complementary 
strand (see Tables S6 and S7, † Fig. 6). In contrast in models for Ru-bip, the non-coordinated phenyl ring of the biphenyl ligand penetrates deeply at the $\mathrm{G}^{3^{*}} \mathrm{pC}^{4}$ or $\mathrm{G}^{6^{*}} \mathrm{pC}^{5}$ base step. The relevant inter-proton distances are consistent with the observed NOE contacts. Observed NOE data are consistent with the model of II-Ru-G ${ }^{3}\left(\mathbf{1}^{\prime}\right)$ : NOEs occur between H1,4 ( 3.45 $\left.\mathrm{A}\right), \mathrm{H} 9,10$ $(\sim 4.73 \AA), \mathrm{H} 2,3(\sim 3.72 \AA)$ and $\mathrm{G}^{3 *} \mathrm{H} 8$, respectively; between $\mathrm{H} 9,10(\sim 4.74 \AA)$ or $\mathrm{H} 1,4(\sim 4.64 \AA)$ and $\mathrm{G}^{3 *} \mathrm{H}^{\prime}$, respectively; between $\mathrm{H} 9,10(\sim 3.71 \AA)$ or $\mathrm{H} 1,4(\sim 3.24 \AA)$ and $\mathrm{C}^{4} \mathrm{H} 6, \mathrm{H} 5,8$ $(\sim 3.60 \AA)$ or $\mathrm{H} 9,10(\sim 4.14 \AA)$ and $\mathrm{C}^{4} \mathrm{H} 1^{\prime}$, respectively; between $\mathrm{H} 6,7(\sim 3.67,3.18$ or $2.52 \AA)$ and $\mathrm{G}^{9} \mathrm{H} 1^{\prime},-\mathrm{H} 2^{\prime}$ or $-\mathrm{H} 2^{\prime \prime}$, respectively; between H6,7 ( 2.94 or $2.69 \AA)$, H5,8 $(\sim 3.08 \AA)$ and $\mathrm{C}^{10} \mathrm{H} 6$ or $\mathrm{C}^{10} \mathrm{H} 1^{\prime}$, respectively and $\mathrm{NHd}(\sim 2.49$ or $3.03 \AA)$ and $\mathrm{G}^{2} \mathrm{H} 8$ or $-\mathrm{H} 2^{\prime}$ in the model, respectively. Observed NOE data are also consistent with the model II-Ru-G ${ }^{6}\left(\mathbf{1}^{\prime}\right)$ : medium and weak NOEs occur between H1,4 ( 2.74 $⿱$ A) or H9,10 $(\sim 2.86 \AA)$ and $\mathrm{G}^{6 *} \mathrm{H} 8$, respectively; between $\mathrm{H} 5,8(\sim 2.55 \AA), \mathrm{H} 9,10(\sim 3.47 \AA)$ and $\mathrm{G}^{6 *} \mathrm{H} 1^{\prime}$, respectively; between $\mathrm{H} 1,4(\sim 2.87 \AA)$ and $\mathrm{C}^{5} \mathrm{H} 6$, $\mathrm{H} 1,4(\sim 3.72 \AA)$ and $\mathrm{C}^{5} \mathrm{H} 1^{\prime}, \mathrm{H} 1,4(\sim 2.66 \AA)$ and $\mathrm{C}^{5} \mathrm{H} 2^{\prime}$, respectively; between H6,7 $(\sim 2.44 \AA)$ and $\mathrm{C}^{7} \mathrm{H} 2^{\prime}, \mathrm{H} 6,7(\sim 2.94 \AA)$ and $\mathrm{C}^{7} \mathrm{H} 1^{\prime}, \mathrm{H} 6,7$ ( 3.01 $), \mathrm{H} 5,8(\sim 2.53 \AA)$ and $\mathrm{C}^{7} \mathrm{H} 2^{\prime \prime}, \mathrm{H} 6,7(\sim 3.44$ $\AA), \mathrm{H} 5,8(\sim 3.50 \AA)$ and $\mathrm{G}^{8} \mathrm{H} 1^{\prime}, \mathrm{H} 5,8(\sim 3.85 \AA), \mathrm{H} 6,7(\sim 3.89 \AA)$ and $\mathrm{G}^{8} \mathrm{H} 2^{\prime} / \mathrm{H}^{\prime \prime}$ in the model, respectively. As shown in Fig. 6, the shortest distance for en $\mathrm{NH} \cdots \mathrm{O}^{3} \mathrm{G}^{3}$ or en $\mathrm{NH} \cdots \mathrm{O}^{6} \mathrm{G}^{6}$ is 2.66 or $2.01 \AA$, larger than that in the reported 9EtG adduct (1.91 $\AA),{ }^{28}$ consistent with weak en-NH resonances observed for IIRu-G ${ }^{3}\left(\mathbf{1}^{\prime}\right)$ and II-Ru-G ${ }^{6}\left(\mathbf{1}^{\prime}\right)$ in $\mathrm{D}_{2} \mathrm{O}$.

The largest downfield shift $(+1.00 \mathrm{ppm})$ is observed for $\mathrm{H} 9,10$ protons of ring $\mathrm{B}$ of $\mathbf{1}^{\prime}$ for mono-ruthenated duplexes II-Ru$\mathrm{G}^{3}\left(\mathbf{1}^{\prime}\right)$ and II-Ru-G $\mathrm{G}^{6}\left(\mathbf{1}^{\prime}\right)$ (Table 1 ), but the shift changes for H6,7 $(+0.09 \mathrm{ppm})$ and $\mathrm{H} 5,8(+0.12 \mathrm{ppm})$ of ring $\mathrm{C}$ of $\mathbf{1}^{\prime}$ are rather small when compared with that for $\mathrm{H} 9,10$. These results are consistent with the base stacking of the non-coordinated rings and formation of short $\mathrm{C}-\mathrm{H} \cdots \mathrm{X}(\mathrm{X}=\mathrm{O} \text { or } \mathrm{N})^{67}$ hydrogen bonds between the protons of non-coordinated rings and bases as shown in models II-Ru-G ${ }^{3}\left(\mathbf{1}^{\prime}\right)$ and II-Ru-G ${ }^{6}\left(\mathbf{1}^{\prime}\right)$ (Fig. 6). It is clear that $\mathrm{H} 5,8$ and $\mathrm{H} 6,7$ protons are located within the confines of the purine ring $\mathrm{G}^{9}$ in model II-Ru- $\mathrm{G}^{3}\left(\mathbf{1}^{\prime}\right)$ or $\mathrm{G}^{6}$ in II-Ru-G $\mathrm{G}^{6}\left(\mathbf{1}^{\prime}\right)$, and the H9,10 protons are located exactly in the middle of the two strands (Fig. 6) and in the ring planes beyond the confines of the purine or pyrimidine rings.

It has been reported that proton chemical shifts may change by up to $+2.1 \mathrm{ppm}$ (downfield) on formation of $\mathrm{C}-\mathrm{H} \cdots \mathrm{X}(\mathrm{X}=\mathrm{O}$ or $\mathrm{N})$ hydrogen bonds. ${ }^{68} \mathrm{It}$ is clear in the present case that the protons of rings $\mathrm{B}$ and $\mathrm{C}$ do sit near the edge of the purine or pyrimidine rings from the models II-Ru-G $\mathrm{G}^{3}\left(\mathbf{1}^{\prime}\right)$ and II-Ru-G ${ }^{6}\left(\mathbf{1}^{\prime}\right)$, and the protons are not directed to the centres of these rings. Other than the fact that protons of ring B are within the arene ring plane in Ru-bip, the H5,8 and $\mathrm{H} 9,10$ protons of $\mathbf{1}^{\prime}$ are located above or below the ring plane in the models. Such orientation makes the distances between $\mathrm{H} 5,8$ or $\mathrm{H} 9,10$ and $\mathrm{N}$ or $\mathrm{O}$ atoms of purine or pyrimidine rings of $\mathrm{G}$ or $\mathrm{C}$ bases nearly 0.9 $\AA$ shorter than those of Ru-bip. For model II-Ru-G ${ }^{3}\left(\mathbf{1}^{\prime}\right)$ : short $\mathrm{H} 9,10 \cdots \mathrm{N} 1$ of $\mathrm{G}^{3}(\sim 2.68 \AA), \mathrm{H} 9,10 \cdots \mathrm{N} 3$ of $\mathrm{C}^{4}(\sim 2.51 \AA)$, $\mathrm{H} 5,8 \cdots \mathrm{N} 1$ or $\mathrm{N} 7$ of $\mathrm{G}^{9}(\sim 2.70$ or $2.75 \AA$, respectively), $\mathrm{H} 5,8 \cdots$ OC2 of $\mathrm{C}^{4}(\sim 2.60 \AA)$, H6,7 $\cdots$ sugar $\mathrm{O}$ of $\mathrm{G}^{9}(\sim 2.58$ or $2.80 \AA$, respectively) distances are observed (Fig. 6a-c). For model II-

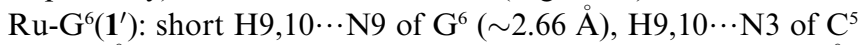
$(\sim 2.54 \AA), \mathrm{H} 5,8 \cdots \mathrm{N} 3$ of $\mathrm{G}^{6}, \mathrm{C}^{7}$ and $\mathrm{G}^{8}(\sim 2.60,2.61$ or $2.61 \AA$, respectively), $\mathrm{H} 6,7 \cdots \mathrm{OC} 2$ of $\mathrm{C}^{7}(\sim 2.59 \AA)$ distances are observed (Fig. 6d-f). Thus, in the present case, the shifts of the protons of rings $\mathrm{B}$ and $\mathrm{C}$ of $\mathbf{1}^{\prime}$ reflect both the downfield shift induced by the formation of $\mathrm{C}-\mathrm{H} \cdots \mathrm{X}(\mathrm{X}=\mathrm{O}$ or $\mathrm{N})$ hydrogen bonding, ${ }^{\mathbf{6}}$ and the upfield shift induced by the intercalation effect on the protons located above or below the intercalator, due to the ring current effect of the aromatic groups. The H9,10 protons are located exactly central to the two strands of DNA, so the downfield shifts for $\mathrm{H} 9,10$ protons are larger (1.0 ppm).

The data imply that in both cases the tha of $\mathbf{1}^{\prime}$ in the models has swung round so that the ring system points across to the opposite strand rather than penetrating so deeply into the strand to which the $\mathrm{Ru}$ centre is attached $\left(\mathrm{G}^{3 *}\right.$ or $\left.\mathrm{G}^{6^{*}}\right)$. This tendency is then likely to be stabilized by tha-base interactions and $\mathrm{C}-\mathrm{H} \cdots \mathrm{X}$ ( $\mathrm{X}=\mathrm{O}$ or $\mathrm{N}$ ) hydrogen bonding within the $\mathrm{G}^{3}$-tha ring- $\mathrm{C}^{4}$ and the $\mathrm{G}^{9}$-tha ring- $\mathrm{C}^{10}$ 'sandwich' as shown in Fig. 6a-c, or within the $\mathrm{G}^{6}$-tha ring- $\mathrm{C}^{5}$ and the $\mathrm{G}^{8}$-tha ring- $\mathrm{C}^{7}$ 'sandwich' as shown in Fig. 6d-f. This kind of intercalation distorts the DNA more than that of aromatic intercalators, such as Ru-bip, and reduces the strength of $\mathrm{H}$-bonding between en- $\mathrm{NH}$ and $\mathrm{G}^{3} \mathrm{O} 6$. The intercalation of the non-coordinated phenyl ring of Ru-bip, ${ }^{22}$ of actinomycin D (ActD) and daunomycin ${ }^{65}$ between the GC step in previous work suggested that steric crowding at the $\mathrm{GpC}$ step is less than that at the GpG step, which thereby allows accommodation of the bulky non-aromatic rings of tha. A further driving force for $\mathrm{GpC}$ rather $\mathrm{GpG}$ intercalation is the weaker purine-pyrimidine $\pi-\pi$ stacking interaction for $\mathrm{GpC}$ compared with purine-purine GpG steps. ${ }^{65}$ It is interesting in the present work that all of the intercalation of $\mathrm{Ru}$-bound tetrahydroanthracene occurs between $\mathrm{GpC}$ base steps, and there is no evidence for intercalation at the $\mathrm{GpG}$ base steps.

\section{Ru-en-NH $\cdots$ GO6 H-bonding}

Two distinct NHu-NHd cross-peaks were identifiable in the $283 \mathrm{~K} 2 \mathrm{D}$ NOESY and 2D ${ }^{15} \mathrm{~N}$-edited NOESY NMR spectra (Table S5 and Figs. 5, S6†), and the downfield shifts of $\mathrm{NH}$ resonances in the adducts are consistent with the presence of $\mathrm{H}$ bonding to the $\mathrm{C} 6$ carbonyl of the coordinated G. ${ }^{22,23,27,28}$ Only one broad peak for $\mathrm{NH}(\mathrm{u})$ was detected in the $2 \mathrm{D}\left[{ }^{1} \mathrm{H},{ }^{15} \mathrm{~N}\right]$ HSQC NMR data at $283 \mathrm{~K}$; the resonance for $\mathrm{NH}(\mathrm{d})$ was too broad to observe (Fig. S3†). NH exchange was rapid for the en$\mathrm{NH}(\mathrm{u})$ protons in the mono-intercalated duplexes II-Ru-G $\mathrm{G}^{3}\left(\mathbf{1}^{\prime}\right)$ and II-Ru-G $\mathrm{G}^{6}\left(\mathbf{1}^{\prime}\right)$ (no ${ }^{1} \mathrm{H} /{ }^{15} \mathrm{~N}$ cross-peaks being detected for a $\mathrm{D}_{2} \mathrm{O}$ solution of II-Ru-G ${ }^{3}\left(\mathbf{1}^{\prime}\right)$ and II-Ru-G $\mathrm{G}^{6}\left(\mathbf{1}^{\prime}\right)$, Fig. S3†). Such a rapid $\mathrm{NH}$ exchange of the en- $\mathrm{NH}(\mathrm{u})$ protons was also observed in the double-intercalated duplex II- $\mathrm{Ru}_{2}-\mathrm{G}^{3} \mathrm{G}^{9}$ (Ru-bip), ${ }^{22}$ suggesting that mono-intercalation of $\mathbf{1}^{\prime}$ into duplex II gives rise to similar effects to that of the di-intercalation of Ru-bip.

\section{Sequence specificity of $\mathbf{G}$ metallation}

Adducts of duplex II eluted as single strands from the reversephase HPLC column ${ }^{22,23}$ (Fig. 2d and 2e) due to the denaturing character of the HPLC solvent. Three mono-ruthenated products (I-Ru-G $\mathbf{G}^{2}, \mathbf{I}-\mathrm{Ru}-\mathrm{G}^{3}$ and I-Ru-G $\left.\mathrm{G}^{6}\right)$ and three di-ruthenated products $\left(\mathbf{I}-\mathrm{Ru}_{2}-\mathrm{G}^{2} \mathrm{G}^{3}, \quad \mathbf{I}-\mathrm{Ru}_{2}-\mathrm{G}^{2} \mathrm{G}^{6}\right.$ and $\left.\mathbf{I}-\mathrm{Ru}_{2}-\mathrm{G}^{3} \mathrm{G}^{6}\right)$ were detected in the $1: 1 \mathbf{1} / \mathbf{I}$ reaction mixture, showing that all three guanine bases can be ruthenated readily in the single-stranded 
hexamer DNA d(CGGCCG) (Table $\mathrm{S} 1 \dagger)$. Only the two monoruthenated products II-Ru-G $\mathrm{G}^{3}$ and II-Ru-G ${ }^{6}$ were detected in the reaction of duplex II with 1 at a $\mathrm{Ru}$ : II molar ratio of $1: 1 ; \mathrm{no} \mathrm{G}^{2}$ ruthenated adduct was detected (Table $\mathrm{S} 1 \dagger$ ). When the above mono-ruthenated products II-Ru-G ${ }^{3}$ and II-Ru-G $\mathrm{G}^{6}$ were reacted with a second mol equiv. of $\mathbf{1}$ at the same temperature, only two mono-ruthenated single strand adducts (I-Ru-G $\mathrm{G}^{3}$ and $\left.\mathbf{I}-\mathrm{Ru}-\mathrm{G}^{6}\right)$ and two di-ruthenated single strand adducts (likely to be $\mathbf{I}-\mathrm{Ru}_{2^{-}}$ $\mathrm{G}^{3} \mathrm{G}^{6}$ and $\mathrm{I}-\mathrm{Ru}_{2}-\mathrm{G}^{2} \mathrm{G}^{6}$ ) eluted from the reverse-phase HPLC column (Table $\mathrm{S} 1 \dagger$ ). The products may therefore involve ruthenation on the same strand: II- $\mathrm{Ru}_{2}-\mathrm{G}^{3} \mathrm{G}^{6}$ and II-Ru $\mathbf{H}_{2}-\mathrm{G}^{2} \mathrm{G}^{6}$, or on different strands: II- $\mathrm{Ru}_{2}-\mathrm{G}^{3} \mathrm{G}^{9}$, II- $R \mathrm{u}_{2}-\mathrm{G}^{6} \mathrm{G}^{9}, \mathbf{I I}-\mathrm{Ru}_{2}-\mathrm{G}^{6} \mathrm{G}^{12}$ and II- $\mathrm{Ru}_{2}-\mathrm{G}^{3} \mathrm{G}^{12}$. No $\mathrm{G}^{8}$ ruthenated duplex adducts such as II- $\mathrm{Ru}_{2^{-}}$ $\mathrm{G}^{3} \mathrm{G}^{8}$ or II-R $\mathrm{u}_{2}-\mathrm{G}^{6} \mathrm{G}^{8}$ were detected. These results are consistent with 2D TOCSY experiments (Fig. 3): the cross-peak intensities of $\mathrm{C}-\mathrm{H} 5 / \mathrm{H} 6\left(\mathrm{C}^{1 \prime}, \mathrm{C}^{4 \prime}\right.$ and $\left.\mathrm{C}^{5 \prime}\right)$ of ruthenated species increased in the $2: 1 \mathbf{1} / \mathrm{II}$ reaction mixture.

The cross-peaks for $\mathrm{H} 5 / \mathrm{H} 6$ resonances of $\mathrm{C}^{5} / \mathrm{C}^{11}$ almost disappeared when the $\mathrm{Ru}:$ II ratio was raised to $3: 1$ (Fig. 3D). This might suggest that the third ruthenation site for the diruthenated duplexes occurs at the un-ruthenated $\mathrm{G}^{6}$ and $\mathrm{G}^{12}$ residues, to form two tri-ruthenated duplex adducts: II- $\mathrm{Ru}_{3^{-}}$ $\mathrm{G}^{3} \mathrm{G}^{6} \mathrm{G}^{12}$ and II- $\mathrm{Ru}_{3}-\mathrm{G}^{2} \mathrm{G}^{6} \mathrm{G}^{12}$. Thus, ruthenation of monoruthenated products II-Ru-G $\mathrm{G}^{3}$ and II-Ru-G $\mathrm{G}^{6}$ might result in three di-ruthenated duplex species: II- $\mathrm{Ru}_{2}-\mathrm{G}^{3} \mathrm{G}^{6}, \mathbf{I I}-\mathrm{Ru}_{2}-\mathrm{G}^{2} \mathrm{G}^{6}$ and II- $\mathrm{Ru}_{2}-\mathrm{G}^{6} \mathrm{G}^{9}$ (Scheme 1, Table $\mathrm{S} 1 \dagger$ ). The HPLC, MS and 2D ${ }^{15} \mathrm{~N}$-decoupled $\left[{ }^{1} \mathrm{H},{ }^{1} \mathrm{H}\right]$ TOCSY NMR data indicate that the selectivity of $\mathrm{G}$ base ruthenation for the free duplex II, monoruthenated duplexes and di-ruthenated duplexes is quite different. For free duplex II, little ruthenation of $\mathrm{G}^{2}$ was observed; for mono-ruthenated duplexes II-Ru-G $\mathrm{G}^{3}$ and II-Ru$\mathrm{G}^{6}$, little ruthenation of $\mathrm{G}^{8}$ was observed; however, the favoured ruthenation site for the di-ruthenated duplexes appears to be $G^{6}$ and $\mathrm{G}^{12}$, the $\mathrm{G}$ bases at the $3^{\prime}$ end. Reactions of complexes Rucym and Ru-bip with duplex II d(CGGCCG) $)_{2}$ at a $\mathrm{Ru}:$ II ratio of $1: 1$, also gave rise to little ruthenation of $\mathrm{G}^{2}{ }^{22}$ However, the II-Ru-G $\mathrm{G}^{3}$ : II-Ru-G $\mathrm{G}^{6}$ ratios in the reaction mixtures with $\mathrm{Ru}:$ II ratio of $1: 1$ are different: $1: 1$ for Ru-cym, $3: 1$ for Ru-bip and $2: 1$ for $\mathrm{Ru}$-tha in the present case, indicating that there is no preference for binding to an internal base or terminal nucleotide for the non-intercalator Ru-cym. In contrast, obvious specificity exists for binding to an internal base for the aromatic intercalator Ru-bip. Specificity for internal bases is also the case for the nonaromatic intercalator $\mathrm{Ru}$-tha. Exclusive attack on the $3^{\prime}-\mathrm{G}\left(\mathrm{G}^{3}\right)$, as seen for these organometallic $\mathrm{Ru}$ arene complexes, is uncommon for platination. There might be two reasons for this. Firstly, the pseudo-octahedral coordination site on an arene $\mathrm{Ru}^{\mathrm{II}}$ complex is more sterically demanding than that of a squareplanar site on $\mathrm{Pt}^{\mathrm{II}}$. In addition, the steric hindrance around each base in DNA sequences is quite different. The combined steric hindrance of $\mathrm{G}$ and $\mathrm{C}$ plus the $\mathrm{Ru}^{\mathrm{II}}$ complex are likely to account for a preferential binding to $G^{3} N 7$ or $G^{6} N 7$ rather than to $G^{2} N 7$ in the free duplex. After ruthenation at $\mathrm{G}^{3}$ or $\mathrm{G}^{6}$, the situation for the non-ruthenated single strand in the mono-ruthenated products II-Ru-G ${ }^{3}$ and II-Ru-G ${ }^{6}$ may be similar to that of the free duplex, so no $\mathrm{G}^{8}$ ruthenation is detected. For the monoruthenated single strand $\mathbf{I}-\mathrm{Ru}-\mathrm{G}^{3}$ or $\mathbf{I}-\mathrm{Ru}-\mathrm{G}^{6}$ in the monoruthenated products $\mathbf{I I}-\mathrm{Ru}-\mathrm{G}^{3}$ and $\mathrm{II}-\mathrm{Ru}-\mathrm{G}^{6}$, steric hindrance around $\mathrm{G}^{2}$ in the mono-ruthenated duplex II-Ru- $\mathrm{G}^{3}$ is much greater than that in the free duplex and for this reason it is believed that no $\mathbf{I I}-\mathrm{Ru}_{2}-\mathrm{G}^{2} \mathrm{G}^{3}$ species is detected. The DNA distortion caused by ruthenation at $\mathrm{N} 7$ of $\mathrm{G}^{6}$ may decrease the steric hindrance around $\mathrm{G}^{2}$ in the mono-ruthenated duplex II$\mathrm{Ru}-\mathrm{G}^{6}$, resulting in formation of the $\mathrm{G}^{2}$-bound di-ruthenated duplex II- $\mathrm{Ru}_{2}-\mathrm{G}^{2} \mathrm{G}^{6}$. Steric hindrance around $\mathrm{G}^{2}$ and $\mathrm{G}^{3}$ in the di-ruthenated duplexes II- $\mathrm{Ru}_{2}-\mathrm{G}^{3} \mathrm{G}^{6}, \mathbf{I I}-\mathrm{Ru}_{2}-\mathrm{G}^{2} \mathrm{G}^{6}$ and II- $\mathrm{Ru}_{2^{-}}$ $\mathrm{G}^{6} \mathrm{G}^{9}$ is even greater, so ruthenation at the end base $\mathrm{G}^{6}$ or $\mathrm{G}^{12}$ as the third site is reasonable.

\section{Bulky lesion and penetrative intercalation}

Reported data ${ }^{44}$ show that the intercalative binding of a bulky intercalator cholesterol group on a modified base of a duplex DNA is a classical intercalation, and the lesion site and the distortions in the structure of the DNA produced by these cholesterol derivatives are somehow similar to those induced by other adducts containing polycyclic aromatic groups. However, the base opposite the modified nucleotide is displaced and the local structure of the double helix is highly distorted. These observations are quite different from those in the present work involving penetrative intercalation of tha into duplex DNA when Ru-tha is coordinated at GN7. It is notable that there is no displacement of the base opposite the modified nucleotide, but $\mathrm{C}-\mathrm{H} \cdots \mathrm{X}(\mathrm{X}=\mathrm{O}$ or $\mathrm{N})$ hydrogen bonding between protons of ring $\mathrm{C}$ of tha and $\mathrm{O}$ or $\mathrm{N}$ atoms of bases opposite the ruthenated nucleotides. The local structure of the ruthenated double helix is highly distorted. Such a highly distorted double helix is not observed in the DNA adducts of platinum complexes with an acridine side arm intercalator, e.g. PT-ACRAMTU ${ }^{56}$ where the threading intercalation occurs at the central base-pair step but does not cause helical bending.

\section{Experimental section}

\section{Materials}

Organometallic ruthenium(II) complex [( $\eta^{6}-$ tha $\left.) \mathrm{Ru}(\mathrm{en}) \mathrm{Cl}\right]\left[\mathrm{PF}_{6}\right]$ $\left(\mathrm{PF}_{6}\right)$ (tha $=1,4,9,10$-tetrahydroanthracene, en $=$ ethylenediamine) and ${ }^{15} \mathrm{~N}$-labeled $1\left({ }^{15} \mathrm{~N}-1\right)$ were synthesised as described previously. ${ }^{27,28}$ The sodium salt of FPLC-purified oligonucleotide d(CGGCCG) I was purchased from Oswel (Southampton, UK) and was further purified by HPLC. Sodium perchlorate and acetonitrile (HPLC grade) were obtained from Fisher, and triethylammonium acetate buffer (TEAA) from Fluka.

\section{High performance liquid chromatography (HPLC)}

This was carried out on reversed-phase columns with TEAA and TEAA/acetonitrile as mobile phases.

\section{HPLC-electrospray ionisation mass spectrometry (HPLC- ESIMS)}

Negative-ion electrospray ionisation mass spectra were obtained on a mass spectrometer interfaced with a reversed phase HPLC column eluted with TEAA/acetonitrile gradients as above. 


\section{NMR spectroscopy}

NMR data were acquired on an $800 \mathrm{MHz}$ or $600 \mathrm{MHz}$ Bruker Avance NMR spectrometer equipped with a multiple resonance TXI $\left({ }^{1} \mathrm{H},{ }^{13} \mathrm{C},{ }^{15} \mathrm{~N},{ }^{31} \mathrm{P}\right) x y z$-gradient probe.

\section{Molecular modelling}

A structure for canonical B-form duplex d(CGGCCG) $)_{2}$ was generated within the biopolymer module of Sybyl (version 6.3, Tripos Inc.). Crystal coordinates from the X-ray crystal structures of 1 allowed accurate representation of the Ru complex to be incorporated into the model Ru-DNA constructs. Docking of the Ru-complex onto $\mathrm{G}^{x} \mathrm{~N} 7(x=3$ or 6 ) of the DNA structure was achieved by manual independent manipulation of both DNA and Ru-complex molecules. The Ru-N7 inter-atomic distance was based on reported crystal structures of Ru-GMP complexes. A pseudo-atom at the centre of the $\eta^{6}$-six-membered aromatic ring ( ring $\mathrm{A}$ ) of tha was attached to the $\mathrm{Ru}$ centre to provide a rotatable bond about which the tha moiety could be manipulated. In a similar way, the Ru-GN7 bond was activated to form a rotatable bond, about which the entire Ru ligand could be rotated independently of the DNA structure. $\mathrm{Ru}-\mathrm{G}^{x} \mathrm{~N} 7$ models were prepared in such a way as to reduce steric contact as far as possible. Constraints were applied where deemed plausible and structures were energy minimized to remove the effects of steric clash.

Details of reactions of II with ${ }^{15} \mathrm{~N}-\mathbf{1}$, HPLC, HPLC-ESI-MS, $\mathrm{NMR}$ and $\mathrm{pH}$ measurements are in the ESI. $\dagger$

\section{Conclusions}

In conclusion, the results presented here provide a rare example of coordinative binding and the penetrative intercalation of a bulky intercalator into DNA, and may help to explain why ruthenium arene complexes have a different mechanism of antitumour activity (perhaps related to recognition by nucleotide repair enzymes) compared to cisplatin. Firstly, the NMR results were indicative of the penetrative intercalation of the tha rings $\mathrm{B}$ and $C$ of $\mathbf{1}^{\prime}$, selectively between two base pairs $\mathrm{G}^{3} / \mathrm{C}^{10}: \mathrm{C}^{4} / \mathrm{G}^{9}$ or $\mathrm{G}^{6} / \mathrm{C}^{7}: \mathrm{C}^{5} / \mathrm{G}^{8}$, which contrasts with that observed between one base pair $\mathrm{G}^{3} / \mathrm{C}^{4}$ and or $\mathrm{G}^{6} / \mathrm{C}^{5}$ for the classic aromatic intercalator Ru-bip. The two slightly different intercalation models for the extended non-aromatic rings of $\mathrm{Ru}$-tha, indicate that the distortion of the DNA duplex is sequence-related. Secondly, large low-field shifts for proton resonances of the intercalated non-coordinated rings $\mathrm{B}$ and $\mathrm{C}$ of tha reflect both the downfield shift induced by the formation of short $\mathrm{C}-\mathrm{H} \cdots \mathrm{X}(\mathrm{X}=\mathrm{O}$ or $\mathrm{N})$ hydrogen bonds and upfield shift induced by the intercalation effect on the protons located above or below the intercalator, due to the ring currents of aromatic groups. The downfield shifts of $\mathrm{H} 9,10$ protons of $\mathbf{1}^{\prime}$ are larger $(+1.0 \mathrm{ppm})$ for they are located exactly in the middle of the two strands. Such deshielding of intercalator NMR resonances is rare, indicating that the intercalative interactions between this bulky tha intercalator and classical aromatic DNA intercalators are somewhat different. Thirdly, the DNA structural perturbations induced by Ru-tha are larger than those observed for Ru-bip and Ru-cym complexes; distortions of base-pair planes are observed around the sites at which the tha has penetrated, and the dynamics of the terminal base ruthenated adduct $\mathbf{I I}-\mathrm{Ru}-\mathrm{G}^{6}\left(\mathbf{1}^{\prime}\right)$ are significantly different from those of internal base ruthenated adduct II-Ru$G^{3}\left(\mathbf{1}^{\prime}\right)$. These findings agree with the fact that the precipitation of DNA duplex adducts of Ru-tha is observed only at very high concentrations compared with Ru-bip, suggesting that the intercalation of sterically bulky tha into a DNA duplex makes the duplex DNA behave differently from intercalation by the aromatic bip. Fourthly, selective ruthenation at $\mathrm{N} 7$ of $\mathrm{G}^{3}$ and $\mathrm{G}^{6}$ in the hexamer DNA duplex is similar to that of Ru-cym and Rubip, but the mono-intercalation of tha reduced the strength of $\mathrm{H}$-bonding between en-NH and GO6 as much as that for the diintercalated di-ruthenated Ru-bip duplex. Intercalation at $\mathrm{GpC}$ by tha appears to have a lower energy penalty when compared with intercalation at GpG base steps, thereby allowing accommodation of the non-aromatic, bulky rings of tha. Although all 3 G's were readily ruthenated at N7 in the single-stranded DNA hexamer, only $\mathrm{G}^{3}$ (or $\mathrm{G}^{9}$ ) and $\mathrm{G}^{6}$, and not $\mathrm{G}^{2}\left(\mathrm{G}^{8}\right)$ were ruthenated in the free DNA duplex which is attributed to unfavorable steric interactions ${ }^{22}$ between the duplex and arene for binding at $\mathrm{G}^{2}\left(\mathrm{G}^{8}\right)$. The different ratios of II-Ru-G $\mathrm{G}^{3}$ : II-Ru-G $\mathrm{G}^{6}$ adducts in the reaction mixtures with $\mathrm{Ru}:$ II ratio of $1: 1$, indicates that there are differences in specificity from binding to internal bases or terminal nucleotides for the non-intercalator Ru-cym, the aromatic intercalator Ru-bip and non-aromatic intercalator Ru-tha. Little ruthenation of $\mathrm{G}^{8}$ was observed in the mono-ruthenated duplexes, but the favorable binding sites were $\mathrm{G}^{6}$ and $\mathrm{G}^{12}$ when di-ruthenated duplexes were reacted with $\left\{\left(\eta^{6}-\right.\right.$ tha) $\mathrm{Ru}(\mathrm{en})\}^{2+}$. These results also demonstrate that the combination of HPLC, ESI-MS together with $2 \mathrm{D}\left[{ }^{1} \mathrm{H},{ }^{1} \mathrm{H}\right]$ TOCSY NMR experiments is powerful for elucidating the selectivity of G-base ruthenation of the free duplex II, mono-ruthenated duplexes and di-ruthenated duplexes. Such knowledge of DNA interactions may be incorporated into design concepts for this class of anticancer agents and assist the exploration of structureactivity relationships.

The coordinative and penetrative intercalative interactions between Ru-tha and duplex DNA are different from that of DNA modified covalently by aromatic or bulky intercalators, in which the displacement or flip-out of bases near the modified sites may occur. Although both involve the modification of a DNA base via coordinative bonding, the penetrative intercalative interactions between Ru-tha and duplex DNA are also different from that of platinum complexes with an acridine side arm intercalator, where the threading intercalation does not cause helical bending. The $\mathrm{C}-\mathrm{H} \cdots \mathrm{X}(\mathrm{X}=\mathrm{O}$ or $\mathrm{N})$ hydrogen bonds between protons of ring $\mathrm{C}$ of tha and $\mathrm{O}$ or $\mathrm{N}$ atoms of bases opposite the ruthenated nucleotides may contribute significantly to the intercalative interaction between $\mathrm{Ru}$-tha and duplex DNA. The fact that penetrative intercalation has rarely been reported for mono-metallointercalators, implies that the direct $\mathrm{Ru}-\mathrm{N}$ bonding may also assist with penetrative intercalation for the bulky tha ligand. Unwinding and distortion, while still maintaining the basic duplex structure, could contribute to the toxicity of the Ru-tha complex by hindering DNA repair. A bulky lesion is one of the six main DNA lesions that may invoke NER, for example, the first and rate-determining step in NER is the recognition of the bulky lesions by the XPC/HR23B protein heterodimer complex. ${ }^{69}$ However, mutations and potentially cancer may result if the bulky lesions are resistant to NER. ${ }^{70}$ The 
high anticancer activity both in vitro and in vivo and the high potency of the tha complex may arise in part from the lack of repair of the lesions formed on DNA by this complex, ${ }^{29}$ and assist with elucidation of structure-activity relationships for this class of complexes.

\section{Acknowledgements}

We thank the Wellcome Trust (Travelling Fellowship for HL), NSF (20871069) and JSSF (BK2008428) and facilities in the Edinburgh Protein Interaction Centre and Oncosense Ltd for their support for this work, Dr Haimei Chen for the gift of some of the complexes and colleagues in the EC COST Action D39 for stimulating discussions.

\section{Notes and references}

1 Y. K. Yan, M. Melchart, A. Habtemariam and P. J. Sadler, Chem. Commun., 2005, 4764.

2 M. J. Clarke, Coord. Chem. Rev., 2003, 236, 209.

3 E. Alessio, G. Mestroni, A. Bergamo and G. Sava, Curr. Top. Med. Chem., 2004, 4, 1525.

4 P. J. Dyson, Chimia, 2007, 61, 698.

5 J. E. Debreczeni, A. N. Bullock, G. E. Atilla, D. S. Williams, H. Bregman, S. Knapp and E. Meggers, Angew. Chem., Int. Ed., 2006, 45, 1580 .

6 M. A. Jakupec and B. K. Keppler, Curr. Top. Med. Chem., 2004, 4, 1575 .

7 F. Schmitt, P. Govindaswamy, G. Süss-Fink, W. Han Ang, P. J. Dyson, L. Juillerat-Jeanneret and B. Therrien, J. Med. Chem., 2008, 51, 1811

8 P. M. Takahara, A. C. Rosenzweig, C. A. Frederick and S. J. Lippard, Nature, 1995, 377, 649.

9 D. B. Zamble and S. J. Lippard, in Cisplatin - Chemistry and Biochemistry of a Leading Anticancer Drug, ed. B. Lippert, WileyVCH, New York, 1999, p. 73.

10 D. Wang and S. J. Lippard, Nat. Rev. Drug Discovery, 2005, 4, 307.

11 B. E. Bowler and S. J. Lippard, Biochemistry, 1986, 25, 3031.

12 W. J. Sundquist, D. P. Bancroft and S. J. Lippard, J. Am. Chem. Soc., 1990, 112, 1590.

13 L. Maresca, C. Pacifico, M. C. Pappadopoli and G. Natile, Inorg. Chim. Acta, 2000, 304, 274

14 J. R. Choudhury and U. Bierbach, Nucleic Acids Res., 2005, 33, 5622.

15 K. E. Erkkila, D. T. Odom and J. K. Barton, Chem. Rev., 1999, 99 2777.

16 L. M. Wilhelmsson, F. Westerlund, P. Lincoln and B. Norden, J. Am. Chem. Soc., 2002, 124, 12092.

17 A. Greguric, G. I. Greguric, T. W. Hambley, J. R. Aldrich-Wright and J. G. Collins, J. Chem. Soc., Dalton Trans., 2002, 849.

18 U. Schatzschneider and J. K. Barton, J. Am. Chem. Soc., 2004, 126, 8630 .

19 M. Kang, A. Chouai, H. T. Chifotides and K. R. Dunbar, Angew Chem., Int. Ed., 2006, 45, 6148.

20 C. Gossens, I. Tavernelli and U. Rothlisberger, J. Am. Chem. Soc., 2008, 130, 10921.

21 P. C. A. Bruijnincx and P. J. Sadler, Curr. Opin. Chem. Biol., 2008, 12, 197.

22 H. K. Liu, F. Y. Wang, J. A. Parkinson, J. Bella and P. J. Sadler, Chem.-Eur. J., 2006, 12, 6151.

23 H. K. Liu, S. J. Berners-Price, F. Y. Wang, J. A. Parkinson, J. J. Xu, J. Bella and P. J. Sadler, Angew. Chem., Int. Ed., 2006, 45, 8153.

24 R. E. Morris, R. E. Aird, P. D. Murdoch, H. M. Chen, J. Cummings, N. D. Hughes, S. Parsons, A. Parkin, G. Boyd, D. I. Jodrell and P. J. Sadler, J. Med. Chem., 2001, 44, 3616 .

25 R. E. Aird, J. Cummings, A. A. Ritchie, M. Muir, R. E. Morris, H. M. Chen, P. J. Sadler and D. I. Jodrell, Br. J. Cancer, 2002, 86, 1652.

26 O. Novakova, H. M. Chen, O. Vrana, A. Rodger, P. J. Sadler and V. Brabec, Biochemistry, 2003, 42, 11544.

27 H. M. Chen, J. A. Parkinson, R. E. Morris and P. J. Sadler, J. Am Chem. Soc., 2003, 125, 173.
28 H. M. Chen, J. A. Parkinson, S. Parsons, R. A. Coxall, R. O. Gould and P. J. Sadler, J. Am. Chem. Soc., 2002, 124, 3064.

29 O. Novakova, J. Kasparkova, V. Bursova, C. Hofr, M. Vojtiskova, H. M. Chen, P. J. Sadler and V. Brabec, Chem. Biol., 2005, 12, 121.

30 H. M. Chen, J. A. Parkinson, O. Novakova, J. Bella, F. Y. Wang, A. Dawson, R. Gould, S. Parsons, V. Brabec and P. J. Sadler, Proc. Natl. Acad. Sci. U. S. A., 2003, 100, 14623.

31 M. Castellano-Castillo, H. Kostrhunova, V. Marini, J. Kasparkova, P. J. Sadler, J. M. Malinge and V. Brabec, J. Biol. Inorg. Chem., 2008, 13, 993

32 C. Lian, H. Robinson and A. H. J. Wang, J. Am. Chem. Soc., 1996, 118, 8791.

33 K. W. Jennette, S. J. Lippard, G. A. Vassiliades and W. R. Bauer, Proc. Natl. Acad. Sci. U. S. A., 1974, 71, 3839.

34 W. I. Sundquist and S. J. Lippard, Coord. Chem. Rev., 1990, 100, 293.

35 B. P. Hudson and J. K. Barton, J. Am. Chem. Soc., 1998, 120, 6877.

36 J. G. Collins, R. M. Rixon and J. R. Aldrich-Wright, Inorg. Chem., 2000, 39, 4377.

37 L. Gonzalez-Bulnes and J. Gallego, J. Am. Chem. Soc., 2009, 131, 7781 .

38 J. Tan, N. E. Geacintov and S. Broyde, J. Am. Chem. Soc., 2000, 122, 3021 .

39 A. J. Danford, D. Wang, Q. Wang, T. D. Tullius and S. J. Lippard, Proc. Natl. Acad. Sci. U. S. A., 2005, 102, 12311.

40 F. Coste, J.-M. Malinge, L. Serre, W. Shepard, M. Roth, M. Leng and C. Zelwer, Nucleic Acids Res., 1999, 27, 1837.

41 Z. Johar, A. Zahn, C. J. Leumann and B. Jaun, Chem.-Eur. J., 2008, 14, 1080.

42 N. E. Geacintov, M. Cosman, B. E. Hingerty, S. Amin, S. Broyde and D. J. Patel, Chem. Res. Toxicol., 1997, 10, 111.

43 M. Lukin and C. de Los Santos, Chem. Rev., 2006, 106, 607.

44 I. Gomez-Pinto, E. Cubero, S. G. Kalko, V. Monaco, G. van der Marel, J. H. van Boom, M. Orozco and C. Gonzalez, J. Biol. Chem., 2004, 279, 24552.

45 K. Brown, B. E. Hingerty, E. A. Guenther, V. V. Krishnan, S. Broyde, K. W. Turteltaub and M. Cosman, Proc. Natl. Acad.Sci. U. S. A., 2001, 98, 8507.

46 Y. Cai, D. J. Patel, N. E. Geacintov and S. Broyde, J. Mol. Biol., 2007, 374, 292.

47 F. A. Tanious, S. F. Yen and W. D. Wilson, Biochemistry, 1991, 30, 1813.

48 D. Sun, M. Hansen and L. Hurley, J. Am. Chem. Soc., 1995, 117, 2430.

49 H. Baruah and U. Bierbach, Nucleic Acids Res., 2003, 31, 4138.

50 Y. J. Chu, S. Sorey, D. W. Hoffman and B. L. Iverson, J. Am. Chem. Soc., 2007, 129, 1304.

51 Y. J. Chu, D. W. Hoffman and B. L. Iverson, J. Am. Chem. Soc., 2009, 131, 3499

52 M. A. Nazif, J. A. Bangert, I. Ott, R. Gust, R. Stoll and W. S. Sheldrick, J. Inorg. Biochem., 2009, 103, 1405.

53 J. X. Dai, C. Punchihewa, P. Mistry, A. T. Ooi and D. Z. Yang, J. Biol. Chem., 2004, 279, 46096.

54 H. Baruah and U. Bierbach, J. Biol. Inorg. Chem., 2004, 9, 335.

55 R. Guddneppanavar, G. Saluta, G. L. Kucera and U. Bierbach, J. Med. Chem., 2006, 49, 3204

56 H. Baruah, M. W. Wright and U. Bierbach, Biochemistry, 2005, 44, 6059 .

57 S. Takenaka, Bull. Chem. Soc. Jpn., 2001, 74, 217.

58 W. A. Kibbe, Nucleic Acids Res., 2007, 35, W43.

59 J. Vinje, J. A. Parkinson, P. J. Sadler, T. Brown and E. Sletten, Chem.-Eur. J., 2003, 9, 1620; J. L. Beck, R. Gupta, T. Urathamakul., N. L. Williamson, M. M. Sheil, J. R. AldrichWright and S. F. Ralph, Chem. Commun., 2003, 626; J. A. Parkinson, Y. Chen, P. D. Murdoch, Z. J. Guo, S. J. BernersPrice, T. Brown and P. J. Sadler, Chem.-Eur. J., 2000, 6, 3636; D. R. Hare, D. Wemmer, S. H. Chou, G. Drobny and B. R. Reid, J. Mol. Biol., 1983, 171, 319

60 S. L. Lam and S. C. F. Au-Yeung, J. Mol. Biol., 1997, 266, 745

61 Y. Kwon, Z. Xi, L. S. Kappen, I. H. Goldberg and X. Gao, Biochemistry, 2003, 42, 1186; G. Hwang, G. B. Jones and I. H. Goldberg, Biochemistry, 2004, 43, 641.

62 E. Alessio, Y. Xu, S. Cauci, G. Mestroni, F. Quadrifoglio, P. Viglino and L. G. Marzilli, J. Am. Chem. Soc., 1989, 111, 7068.

63 M. D. Reily and L. G. Marzilli, J. Am. Chem. Soc., 1986, 108, 8299. 
64 V. M. Rodriguez-Bailey and M. J. Clarke, Inorg. Chem., 1997, 36, 1611.

65 A. Mukherjee, R. Lavery, B. Bagchi and J. T. Hynes, J. Am. Chem. Soc., 2008, 130, 9747; M. J. L. Cocco, L. A. Hanakahi, M. D. Huber and N. Maizels, Nucleic Acids Res., 2003, 31, 2944

Y. Coppel, J. F. Constant, C. Coulombeau, M. Demeunynck, J. Garcia and J. Lhomme, Biochemistry, 1997, 36, 4831; W. D. Wilson, Y. Li and J. M. Veal, in Advances in DNA Sequence Specific Agents, ed. L. H. Hurley, Elsevier, New York 1992, p. 89; J. Lee, V. Guelev, S. Sorey, D. W. Hoffman and B. L. Iverson, J. Am. Chem. Soc., 2004, 126, 14036; X. G. Liang, H. Asanuma, H. Kashida, A. Takasu, T. Sakamoto, G. Kawai and M. Komiyama, J. Am. Chem. Soc., 2003, 125, 16408.
$66 \mathrm{~K}$. Wuthrich, NMR of Proteins and Nucleic Acids, John Wiley and Sons, Inc., USA, 1986, p. 30.

67 K. Kobayashi, Y. Asakawa, Y. Kikuchi, H. Toi and Y. Aoyama, J. Am. Chem. Soc., 1993, 115, 2648; K. Gkionis, J. A. Platts and J. G. Hill, Inorg. Chem., 2008, 47, 3893.

68 J. Sola, A. Riera, X. Verdaguer and M. A. Maestro, J. Am. Chem. Soc., 2005, 127, 13629; A. Uldry, J. M. Griffin, J. R. Yates, M. Pérez-Torralba, M. D. Santa Maria, A. L. Webber, M. L. L. Beaumont, A. Samoson, R. M. Claramunt, C. J. Pickard and S. P. Brown, J. Am. Chem. Soc., 2008, 130, 945.

69 B. S. Thoma and K. M. Vasquez, Mol. Carcinog., 2003, 38, 1.

70 A. Luch, Nat. Rev. Cancer, 2005, 5, 113; M. S. Greenblatt, W. P. Bennett, M. Hollstein and C. C. Harris, Cancer Res., 1994, 54, 4855. 